Article

\title{
Chemical Composition of Natural Hydrolates and Their Antimicrobial Activity on Arcobacter-Like Cells in Comparison with Other Microorganisms
}

\author{
David Šilha ${ }^{1, * \mathbb{C}}$, Karolína Švarcová ${ }^{1}{ }^{\mathbb{D}}$, Tomáš Bajer ${ }^{2}{ }^{2}$ Karel Královec $^{1}{ }^{1}$, Eliška Tesařová ${ }^{1}$, \\ Kristýna Moučková ${ }^{2}$ (D), Marcela Pejchalová ${ }^{1}$ and Petra Bajerová ${ }^{2, *(\mathbb{D})}$ \\ 1 Department of Biological and Biochemical Sciences, Faculty of Chemical Technology, University of Pardubice, \\ Studentská 573, 53210 Pardubice, Czech Republic; karolina.svarcova@student.upce.cz (K.Š.); \\ karel.kralovec@upce.cz (K.K.); eliska.tesarova@student.upce.cz (E.T.); marcela.pejchalova@upce.cz (M.P.) \\ 2 Department of Analytical Chemistry, Faculty of Chemical Technology, University of Pardubice, \\ Studentská 573, 53210 Pardubice, Czech Republic; tomas.bajer@upce.cz (T.B.); \\ kristyna.mouckova@student.upce.cz (K.M.) \\ * Correspondence: david.silha@upce.cz (D.Š.); petra.bajerova@upce.cz (P.B.); \\ Tel.: +420-466-037-765 (D.Š.); +420-466-037-078 (P.B.)
}

Received: 9 November 2020; Accepted: 27 November 2020; Published: 30 November 2020

\begin{abstract}
Hydrolates obtained via the hydrodistillation and steam distillation of Lavandula angustifolia Mill., Syzygium aromaticum L., Foeniculum vulgare Mill., and Laurus nobilis L. were analyzed by gas chromatography with flame ionization detector (GC-FID) and gas chromatography coupled to mass spectrometry (GC-MS). Additionally, the hydrolates were evaluated for antimicrobial activity (disk-diffusion and microdilution method), influence on biofilm formation (Christensen method) and cytotoxicity of concentrated hydrolates against human cell lines (A549) by xCELLigence system. Using chemical analysis, 48, 9, 13 and 33 different components were detected in lavender, clove, fennel and laurel hydrolates, respectively. Lavender hydrolate contained the largest proportion of 1,8-cineol, linalool furanoxide, and linalool. The main components of laurel hydrolate were 1,8-cineol, 4-terpineol and $\alpha$-terpineol. Fenchone and estragole were the most abundant in fennel hydrolate, and eugenol and eugenyl acetate in clove hydrolate. Concentrated hydrolates showed significant antimicrobial activity. Clove hydrolate was among the most antimicrobially active agents, most preferably against $C$. albicans, with an inhibition zone up to $23.5 \mathrm{~mm}$. Moreover, concentrated hydrolates did not show any cytotoxic effect again8 st human A549 cells. In the presence of the non-concentrated hydrolates, significantly reduced biofilm formation was observed; however, with concentrated clove hydrolate, there was an increase in biofilm formation, e.g., of $A$. thereius, A. lanthieri, and $A$. butzleri. Research shows new findings about hydrolates that may be important in natural medicine or for preservation purposes.
\end{abstract}

Keywords: Lavandula angustifolia; Syzygium aromaticum; Foeniculum vulgare; Laurus nobilis; hydrolates; distillation; Arcobacter-like bacteria; antimicrobial activity; biofilm formation; gas chromatography

\section{Introduction}

Essential oils (EOs) are an example of highly volatile and water-insoluble plant substances. The chemical composition of EOs is highly complex. The main components include monoterpenes and sesquiterpenes [1-3], and they may also contain aldehydes, alcohols, ketones, acids, esters, or phenylpropanoids [4-8]. EOs can be extracted from plants by several methods. One of the oldest and most used methods is distillation [2]. Aqueous solutions obtained as by-products of the distillation of EOs are known as hydrolates or hydrosols $[9,10]$. Hydrolates have an intense herbal aroma and consist 
mainly of water and plant material components. Overall, they contain many bioactive hydrophilic substances [11]. Hydrolates are less described in the literature than EOs. However, it is known that the difference in the composition of a hydrolate from that of an EO is mainly quantitative [6].

Hydrolates also generally contain fewer components, or components at lower concentrations than essential oils, but they still exhibit interesting antimicrobial effects against the microorganisms of interest. Thus, they can be used in medicine or also as a potential preservative in the food industry [11-15]. The antimicrobial properties of substances are often influenced by the agronomic area of cultivation and processing of the plant, which affect the proportion of active ingredients $[16,17]$. Given the increasing resistance of microorganisms, it is appropriate to pay attention to the antimicrobial effects of natural substances, even in synergistic combination with certain antibiotics $[11,18,19]$. The main problem is the resistance of a microorganism with pathogenic potential. Such microorganisms include, but are not limited to, the Arcobacter-like bacteria. Arcobacters are Gram-negative, slender, spiral-shaped rods, and belong to the family Arcobacteraceae [20]. The association of arcobacters with human disease has been demonstrated for A. butzleri, A. cryaerophilus, A. skirrowii and A. thereius species [21,22]. For these bacteria, survival in the form of planktonic cells or in a biofilm is essential, as they can thus better colonize hosts or contaminate food factory environments $[23,24]$. The major routes of arcobacters transmission to humans include consumption of contaminated foods of animal origin and drinking non-treated water $[25,26]$.

The aim of this study was to broaden the current knowledge of the chemical composition and antimicrobial activity of hydrolates obtained from lavender (Lavandula angustifolia Mill.), clove (Syzygium aromaticum L.), fennel (Foeniculum vulgare Mill.), and bay leaves (Laurus nobilis L.). All of these natural matrices are widely available, but to date studies have not looked at testing hydrolates obtained from these matrices. Individual hydrolates obtained by distillation were subjected to chemical analysis by gas chromatography with flame ionization detector (GC-FID) and gas chromatography coupled to mass spectrometry (GC-MS). The antimicrobial activity of the obtained hydrolates was determined by the disc diffusion method, and minimal inhibitory/bactericidal concentration (MIC/MBC) was evaluated by microdilution method. The biofilm formation of microorganisms in the presence of the tested hydrolates was followed by a modified Christensen method in microtiter plates. As far as we know, the effect of natural hydrolates on Arcobacter-like bacteria and others has not yet been described, although resistance to commonly used antibiotics observed among Arcobacter-like cells emphasizes the importance of research in this area of natural compounds [27-31].

\section{Results and Discussion}

\subsection{Chemical Composition of Hydrolates}

Table 1 lists some results of the analysis of concentrated hydrolates obtained by steam distillation $\left(\mathrm{H}_{\mathrm{SD} \_\mathrm{SPE}}\right)$ and hydrodistillation $\left(\mathrm{H}_{\mathrm{HD}} \mathrm{SPE}\right)$. The analyzed hydrolates, especially from lavender and laurel, were rich in a number of compounds. When comparing the results with respect to the hydrolate obtained by hydrodistillation $\left(\mathrm{H}_{\mathrm{HD}}\right)$ and steam distillation $\left(\mathrm{H}_{\mathrm{SD}}\right)$, more compounds were detected in the extracts from steam distillation (SD) hydrolates. This was probably caused by the more favorable conditions during steam distillation. During hydrodistillation, the plant material is in contact with boiling water throughout the distillation, and some of the volatile compounds may be converted (via oxidative reactions, polymerization and hydrolysis) into different substances [32]. The content of individual compounds is expressed as a percentage of the total peak area in the chromatograms obtained by the GC-FID analysis of $\mathrm{H}_{\mathrm{SD} \_S P E}$ extracts and $\mathrm{H}_{\mathrm{HD} \_S P E}$ extracts, so these are approximate values. 
Table 1. Comparison of analyses of $\mathrm{H}_{\mathrm{SD} \_\mathrm{SPE}}$ and $\mathrm{H}_{\mathrm{HD}} \mathrm{SPE}$ extracts by means of peaks in chromatograms, identified compounds and three major components, $n=3$.

\begin{tabular}{|c|c|c|c|c|c|c|}
\hline \multirow{2}{*}{$\begin{array}{l}\text { Hydrolate } \\
\text { from }\end{array}$} & \multicolumn{2}{|c|}{ Peaks in Chromatograms } & \multicolumn{2}{|c|}{$\begin{array}{l}\text { Identified Compounds } \\
\text { (Total Rel. Content) }\end{array}$} & \multicolumn{2}{|c|}{ Main Compounds (Rel. Content) } \\
\hline & $\mathrm{H}_{\mathrm{SD} \_ \text {SPE }}$ & $\mathrm{H}_{\mathrm{HD} \_\mathrm{SPE}}$ & $\mathrm{H}_{\mathrm{SD} \_\mathrm{SPE}}$ & $\mathrm{H}_{\mathrm{HD} \_S P E}$ & $\mathrm{H}_{\mathrm{SD} \_S P E}$ & $\mathbf{H}_{\text {HD_SPE }}$ \\
\hline Lavender & 186 & 172 & $48(90.0 \%)$ & $48(93.2 \%)$ & $\begin{array}{l}\text { 1,8-Cineole }(20.6 \%) \\
(Z) \text {-Linalool } \\
\text { furanoxide }(11.9 \%) \\
\alpha \text {-Terpineol }(10.4 \%)\end{array}$ & $\begin{array}{c}\text { Linalool }(23.2 \%) \\
\text { 1,8-Cineole }(19.5 \%) \\
\alpha \text {-Terpineol }(13.0 \%)\end{array}$ \\
\hline Bay leaves & 227 & 166 & $33(78.0 \%)$ & $33(79.4 \%)$ & $\begin{array}{l}\text { 1,8-Cineol }(56.4 \%) \\
\text { 4-Terpineol }(6.0 \%) \\
\alpha \text {-Terpineol }(5.0 \%)\end{array}$ & $\begin{array}{l}\text { 1,8-Cineol }(54.1 \%) \\
4 \text {-Terpineol }(7.1 \%) \\
\alpha \text {-Terpineol }(6.4 \%)\end{array}$ \\
\hline Fennel & 87 & 68 & $13(84.1 \%)$ & $11(85.1 \%)$ & $\begin{array}{c}\text { Estragole }(37.4 \%) \\
\text { Fenchone } 22.5 \%) \\
p \text {-Methoxy } \\
\text { Cinnamaldehyde } \\
(7.0 \%)\end{array}$ & $\begin{array}{c}\text { Estragole }(33.0 \%) \\
\text { Fenchone }(26.5 \%) \\
\text { Eugenol }(5.6 \%)\end{array}$ \\
\hline Clove & 98 & 80 & $9(99.3 \%)$ & $9(99.3 \%)$ & $\begin{array}{c}\text { Eugenol }(89.1 \%) \\
\text { Eugenyl acetate } \\
(9.3 \%) \\
\text { Chavicol }(0.4 \%)\end{array}$ & $\begin{array}{c}\text { Eugenol }(92.7 \%) \\
\text { Eugenyl acetate } \\
(5.6 \%) \\
\text { Chavicol }(0.4 \%)\end{array}$ \\
\hline
\end{tabular}

$\mathrm{H}_{\mathrm{HD} S \mathrm{SPE}}$ - hydrolate obtained by hydrodistillation and $50 \times$ concentrated using solid phase extraction (SPE);

$\mathrm{H}_{\mathrm{SD}}$ SPE - hydrolate obtained by steam distillation and $50 \times$ concentrated using SPE.

\subsubsection{Lavender Hydrolates}

In total, 48 compounds (Table 2) were identified by mass spectrometry and by comparing the calculated retention indexes with the literature data. The identified compounds amounted to $93.2 \%$ in the $\mathrm{H}_{\mathrm{HD} \_\mathrm{SPE}}$ extracts and $90.0 \%$ in the $\mathrm{H}_{\mathrm{SD} \_\mathrm{SPE}}$ extracts. The major group of identified compounds was oxidized monoterpenes (34 identified compounds that accounted for $86.5 \%$ in the $\mathrm{H}_{\mathrm{HD}} \mathrm{SPE}$ extract and $82.3 \%$ in the $\mathrm{H}_{\mathrm{SD} \_ \text {SPE }}$ extract). The biggest difference in the chemical compositions of both extracts from lavender hydrolates was in the content of linalool ( $23.2 \%$ in the $\mathrm{H}_{\mathrm{HD} \_\mathrm{SPE}}, 7.9 \%$ in the $\left.\mathrm{H}_{\mathrm{SD} \_\mathrm{SPE}}\right)$. Linalool is one of the major compounds of lavender oils. Another major compound in lavender oils is linalyl acetate. The decomposition of linalyl acetate to linalool due to hydrolysis has been reported [33], and could be the main cause of the higher content of linalool in the hydrolate obtained by hydrodistillation (HD) due to the more unfavorable conditions in HD than in SD. A relatively high difference was observed in the content of coumarins (namely coumarin and 7-methoxycoumarin; $\mathrm{H}_{\mathrm{SD} \_\mathrm{SPE}} 3.8 \%$ in total, $\mathrm{H}_{\mathrm{HD} \_S P E} 0.9 \%$ in total), and also in the proportion of linalool derivatives (mainly furanoxides and pyranoxides; $\mathrm{H}_{\mathrm{SD} \_\mathrm{SPE}} 23.5 \%$ in total, $\mathrm{H}_{\mathrm{HD} \_\mathrm{SPE}} 15.7 \%$ in total). The second most abundant compound in the extracts was 1,8-cineol, the content of which was similar $(20.6 \%$ in the $\mathrm{H}_{\mathrm{SD} \_\mathrm{SPE}}$ extract, $19.5 \%$ in the $\mathrm{H}_{\mathrm{HD} \_\mathrm{SPE}}$ extract). 
Table 2. List of compounds identified in hydrolate extracts from Lavandula angustifolia Mill.

\begin{tabular}{|c|c|c|c|c|}
\hline \multirow{2}{*}{ CAS } & \multirow{2}{*}{ Compound } & \multirow{2}{*}{ RI } & \multicolumn{2}{|c|}{$\%$ of Total Peak Area } \\
\hline & & & $\mathbf{H}_{\text {SD_SPE }}$ & H $_{\text {HD_SPE }}$ \\
\hline \multicolumn{5}{|c|}{ Oxidized Monoterpenes } \\
\hline $7392-19-0$ & Bois de Rose oxide/Linaloyl oxide & 968 & 0.2 & 0.1 \\
\hline $54750-70-8$ & (E)-Dehydroxy linalool oxide & 987 & 0.1 & 0.1 \\
\hline $54750-69-5$ & (Z)-Dehydroxy linalool oxide & 1004 & 0.1 & $<0.1$ \\
\hline $470-67-7$ & 1,4-Cineol & 1014 & $<0.1$ & $<0.1$ \\
\hline $470-82-6$ & 1,8-Cineole & 1030 & 20.6 & 19.5 \\
\hline $5989-33-3$ & (Z)-Linalool furanoxide & 1070 & 11.9 & 7.9 \\
\hline $34995-77-2$ & (E)-Linalool furanoxide & 1086 & 9.1 & 5. 9 \\
\hline $78-70-6$ & Linalool & 1101 & 7.9 & 23.2 \\
\hline $29957-43-5$ & Hotrienol & 1103 & 0.8 & 0.5 \\
\hline $471-16-9$ & Sabinol & 1139 & 0.1 & 0.2 \\
\hline $76-22-2$ & Camphor & 1144 & 0.4 & 0.5 \\
\hline - & Lilac aldehyde isomer (B or C) & 1148 & $<0.1$ & $<0.1$ \\
\hline $1786-08-9$ & Nerol oxide & 1151 & 0.4 & 0.2 \\
\hline 5986-38-9 & (E)-Ocimenol & 1154 & $<0.1$ & $<0.1$ \\
\hline $513-20-2$ & Sabina ketone & 1158 & $<0.1$ & $<0.1$ \\
\hline $30460-92-5$ & Pinocarvone & 1160 & $<0.1$ & $<0.1$ \\
\hline $53447-47-5$ & Lilac aldehyde D & 1163 & $<0.1$ & $<0.1$ \\
\hline 14009-71-3 & (Z)-Linalool pyranoxide & 1169 & 1.3 & 1.1 \\
\hline $39028-58-5$ & (E)-Linalool pyranoxide & 1174 & 1.0 & 0.8 \\
\hline $562-74-3$ & 4-Terpineol & 1179 & 1.1 & 1.2 \\
\hline $500-02-7$ & Cryptone & 1185 & 0.9 & 0.8 \\
\hline $13741-21-4$ & 2,6-Dimethyl-3,7-octadiene-2,6-diol & 1190 & 5.9 & 2.2 \\
\hline $98-55-5$ & $\alpha$-Terpineol & 1194 & 10.4 & 13.0 \\
\hline $80-57-9$ & Verbenone & 1207 & 0.2 & 0.2 \\
\hline $1197-07-5$ & $(E)$-Carveol & 1219 & $<0.1$ & $<0.1$ \\
\hline $106-25-2$ & Nerol & 1225 & 0.7 & 0.9 \\
\hline $18675-34-8$ & Neodihydrocarveol & 1231 & 5.9 & 4.9 \\
\hline $122-03-2$ & Cuminaldehyde & 1240 & 0.1 & 0.1 \\
\hline $106-24-1$ & Geraniol & 1252 & 1.0 & 2.3 \\
\hline $51276-33-6$ & 2,6-Dimethyl-1,7-octadien-3,6-diol & 1273 & 1.1 & 0.3 \\
\hline $536-60-7$ & Cumin alcohol & 1291 & 0.4 & 0.3 \\
\hline $39725-34-3$ & 4-Hydroxy-cryptone & 1322 & 0.2 & $<0.1$ \\
\hline $160152-34-1$ & 3-Oxo-p-menth-1-en-7-al & 1336 & 0.1 & $<0.1$ \\
\hline $7712-46-1$ & 8-Hydroxycarvotanacetone & 1427 & $<0.1$ & $<0.1$ \\
\hline $26184-88-3$ & $\alpha$-Bisabolol oxide B & 1653 & 0.1 & 0.1 \\
\hline $3790-71-4$ & $(2 Z, 6 E)$-Farnesol & 1684 & 0.2 & 0.2 \\
\hline \multicolumn{5}{|l|}{ Others } \\
\hline $111-27-3$ & Hexyl alcohol & 872 & 0.2 & 0.2 \\
\hline $3391-86-4$ & 1-Octen-3-ol & 981 & 0.2 & 0.2 \\
\hline $589-98-0$ & 3-Octanol & 999 & 0.1 & 0.1 \\
\hline $106-68-3$ & 3-Octanone & 985 & 0.8 & 0.9 \\
\hline - & Cymene isomer & 1022 & $<0.1$ & $<0.1$ \\
\hline $1073-11-6$ & Lavender lactone & 1035 & 0.8 & 2.0 \\
\hline $1604-28-0$ & 6-Methyl-3,5-heptadien-2-one & 1103 & 0.6 & 0.7 \\
\hline 24903-95-5 & Nopinone & 1137 & 0.2 & 0.1 \\
\hline $97-53-0$ & Eugenol & 1351 & 0.5 & 1.3 \\
\hline 91-64-5 & Coumarin & 1432 & 3.6 & 0.8 \\
\hline $17092-92-1$ & Dihydroactinidiolide & 1524 & $<0.1$ & $<0.1$ \\
\hline $531-59-9$ & 7-Methoxycoumarin (Hernianin) & 1720 & 0.2 & $<0.1$ \\
\hline
\end{tabular}

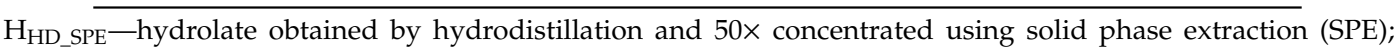
$\mathrm{H}_{\mathrm{SD} S \mathrm{SP}}$ - hydrolate obtained by steam distillation and 50x concentrated using SPE; RI —retention index relative to $n$-alkanes on SLB-5ms capillary column.

\subsubsection{Bay Leaves Hydrolates}

In total, 33 compounds were identified in both types of hydrolates (Table 3). The identified compounds amounted to $78.0 \%$ in the $\mathrm{H}_{\mathrm{HD} \_\mathrm{SPE}}$ extracts and $79.4 \%$ in the $\mathrm{H}_{\mathrm{SD} \_\mathrm{SPE}}$ extracts. The composition of both hydrolates was similar with respect to the identified compounds. Most of the identified compounds were oxidized monoterpenes (22 compounds accounted for $72.1 \%$ in the $\mathrm{H}_{\mathrm{SD} \_\mathrm{SPE}}$ extracts and $73.2 \%$ in the $\mathrm{H}_{\mathrm{HD} \_S P E}$ extracts). The dominant compound in both types of extracts was 1,8 -cineol (56.4\% in the $\mathrm{H}_{\mathrm{SD} \_\mathrm{SPE}}$ extract, $54.1 \%$ in the $\mathrm{H}_{\mathrm{HD} \_\mathrm{SPE}}$ extract). Additionally, the EO of this matrix contains especially high levels of 1,8-cineol, linalool and R-terpinylacetate, as well as benzene compounds (eugenol, methyleugenol and elemicin) [34]. 
Table 3. List of compounds identified in hydrolate extracts from Laurus nobilis L.

\begin{tabular}{|c|c|c|c|c|}
\hline \multirow{2}{*}{ CAS } & \multirow{2}{*}{ Compound } & \multirow{2}{*}{ RI } & \multicolumn{2}{|c|}{ \% of Total Peak Area } \\
\hline & & & HSD_SPE $_{\text {SP }}$ & $\mathbf{H}_{\text {HD_SPE }}$ \\
\hline \multicolumn{5}{|c|}{ Oxidized Monoterpenes } \\
\hline $470-67-7$ & 1,4-Cineol & 1014 & $<0.1$ & $<0.1$ \\
\hline $470-82-6$ & 1,8-Cineol & 1030 & 56.4 & 54.0 \\
\hline $78-70-6$ & Linalool & 1099 & 0.3 & 0.5 \\
\hline $29957-43-5$ & Hotrienol & 1101 & $<0.1$ & $<0.1$ \\
\hline $36262-12-1$ & Dehydrosabina ketone & 1120 & 0.1 & 0.1 \\
\hline $471-16-9$ & Sabinol & 1136 & $<0.1$ & $<0.1$ \\
\hline $1786-08-9$ & Nerol oxide & 1151 & $<0.1$ & $<0.1$ \\
\hline $513-20-2$ & Sabina ketone & 1157 & 0.5 & 0.6 \\
\hline $30460-92-5$ & Pinocarvone & 1160 & 0.4 & 0.3 \\
\hline $562-74-3$ & 4-Terpineol & 1178 & 6.0 & 7.1 \\
\hline 13741-21-4 & 2,6-Dimethyl-3,7-octadiene-2,6-diol & 1189 & 0.7 & 0.4 \\
\hline $98-55-5$ & $\alpha$-Terpineol & 1193 & 5.0 & 6.4 \\
\hline $80-57-9$ & Verbenone & 1207 & $<0.1$ & $<0.1$ \\
\hline $99-48-9$ & Carveol & 1218 & 0.2 & 0.4 \\
\hline $18679-48-6$ & 2-Hydroxy-1,8-cineole & 1225 & 0.4 & 0.5 \\
\hline $22626-43-3$ & cis- $p$-Mentha-1(7),8-diene-2-ol & 1228 & 0.5 & 0.8 \\
\hline $494-99-5$ & Homoveratrole & 1236 & $<0.1$ & $<0.1$ \\
\hline $122-03-2$ & Cuminaldehyde & 1240 & $<0.1$ & $<0.1$ \\
\hline 51276-33-6 & 2,6-Dimethyl-1,7-octadien-3,6-diol & 1272 & 0.4 & 0.2 \\
\hline $536-60-7$ & Cumin alcohol & 1288 & 0.7 & 1.3 \\
\hline 89-83-8 & Thymol & 1298 & 0.2 & 0.1 \\
\hline $22539-72-6$ & $p$-Mentha-1,4-dien-7-ol & 1328 & 0.2 & 0.2 \\
\hline \multicolumn{5}{|l|}{ Others } \\
\hline $100-52-7$ & Benzaldehyde & 960 & $<0.1$ & $<0.1$ \\
\hline $110-93-0$ & 6-Methyl-5-hepten-2-one & 985 & $<0.1$ & 0.2 \\
\hline $1073-11-6$ & Lavender lactone & 1037 & $<0.1$ & 0.1 \\
\hline $6090-09-1$ & Limona ketone & 1130 & $<0.1$ & $<0.1$ \\
\hline $76-49-3$ & Bornyl acetate & 1283 & $<0.1$ & $<0.1$ \\
\hline $81781-24-0$ & \multicolumn{2}{|c|}{$\begin{array}{l}\text { 1,3,3-Trimethyl-2-oxabicyclo[2.2.2]octan-5-yl } \\
\text { acetate }\end{array}$} & 1.0 & 1.2 \\
\hline $97-53-0$ & Eugenol & 1350 & 2.2 & 2.4 \\
\hline $57709-95-2$ & \multicolumn{2}{|c|}{$\begin{array}{l}\text { 1,3,3-Trimethyl-2-oxabicyclo[2.2.2] octan-6-yl } \\
\text { acetate }\end{array}$} & 0.1 & 0.1 \\
\hline $121-33-5$ & Vanilin & 1393 & 0.5 & 0.3 \\
\hline $93-15-2$ & Methyleugenol & 1399 & 1.8 & 1.7 \\
\hline 17092-92-1 & Dihydroactinidiolide & 1524 & 0.2 & $<0.1$ \\
\hline
\end{tabular}

$\mathrm{H}_{\mathrm{HD} S \mathrm{SPE}}$ - hydrolate obtained by hydrodistillation and $50 \times$ concentrated using solid phase extraction (SPE); $\mathrm{H}_{\mathrm{SD} \_\mathrm{SPE}}$ - hydrolate obtained by steam distillation and 50x concentrated using SPE; RI—retention index relative to $n$-alkanes on SLB-5ms capillary column.

\subsubsection{Fennel Hydrolates}

In total, 13 compounds were identified in both types of hydrolates (Table 4), and these compounds amounted to $84.1 \%$ in the $\mathrm{H}_{\mathrm{SD} \_\mathrm{SPE}}$ extracts and $85.1 \%$ in the $\mathrm{H}_{\mathrm{HD} \_\mathrm{SPE}}$ extracts. The main compounds in hydrolates were estragole and fenchone; both compounds formed almost $50 \%$ of the extracts. Estragole and fenchone are the major components of fennel EOs [35-37]. Furthermore, estragole was characterized as one of the key odorants in fennel EOs [38]. Another major constituent (often the most abundant compound) of fennel EOs, (E)-anethole, was not identified. 
Table 4. List of compounds identified in hydrolate extracts from Foeniculum vulgare Mill.

\begin{tabular}{ccccc}
\hline & & & \multicolumn{2}{c}{$\%$ of Total Peak Area } \\
CAS & Compound & RI & H $_{\text {SD_SPE }}$ & H HD_SPE $_{\text {HD }}$ \\
\hline $142-62-1$ & Capronic acid & 982 & 0.2 & n.i. \\
$470-82-6$ & $1,8-C i n e o l$ & 1030 & 2.8 & 3.8 \\
$122-78-1$ & Phenylacetaldehyde & 1042 & 0.1 & n.i. \\
$1195-79-5$ & Fenchone & 1086 & 22.5 & 26.5 \\
$78-70-6$ & Linalool & 1099 & 0.3 & 0.2 \\
$76-22-2$ & Camphor & 1144 & 0.7 & 0.9 \\
$140-67-0$ & Estragole & 1196 & 37.4 & 33.0 \\
$99-48-9$ & Carveol & 1218 & 2.6 & 2.3 \\
$99-49-0$ & Carvone & 1242 & 2.2 & 2.3 \\
$123-11-5$ & p-Anisaldehyde & 1253 & 5.2 & 5.5 \\
$97-53-0$ & Eugenol & 1350 & 2.5 & 5.6 \\
$93-28-7$ & Eugenyl acetate & 1513 & 0.8 & 1.0 \\
$1963-36-6$ & $p$-Methoxy Cinnamaldehyde & 1567 & 7.1 & 4.0 \\
\hline
\end{tabular}

$\mathrm{H}_{\mathrm{HD} \_\mathrm{SPE}}$ - hydrolate obtained by hydrodistillation and 50x concentrated using solid phase extraction (SPE);

$\mathrm{H}_{\mathrm{SD} \_ \text {SPE }}$-hydrolate obtained by steam distillation and 50x concentrated using SPE; RI-retention index relative to $n$-alkanes on SLB-5ms capillary column.

\subsubsection{Clove Hydrolates}

In total, 9 identified compounds (Table 5) amounted to $99.3 \%$ in both extracts. The major group of identified compounds were phenolic derivatives, namely eugenol (E, 92.7\% in $\mathrm{H}_{\mathrm{HD} \_\mathrm{SPE}}$ extract, 89.1\% in $\mathrm{H}_{\mathrm{SD} \_S P E}$ extract) and eugenyl acetate (EA, 9.4\% in $\mathrm{H}_{\mathrm{SD} \_S P E}$ extract, 5.6\% in $\mathrm{H}_{\mathrm{HD} \_S P E}$ extract). The difference in the E/EA ratio is given by the more unfavorable conditions during HD than during SD. Eugenyl acetate is hydrolyzed to form eugenol. It is similar to linalyl acetate, which is hydrolyzed during the hydrodistillation of lavender oil (see 2.1.1).

Table 5. List of compounds identified in hydrolate extracts from Syzygium aromaticum L.

\begin{tabular}{ccccc}
\hline \multirow{2}{*}{ CAS } & Compound & \multirow{2}{*}{ RI } & \multicolumn{2}{c}{ \% of Total Peak Area } \\
& & & HSD_SPE $_{\text {SP }}$ & H HD_SPE $_{\text {HD }}$ \\
\hline $97-53-0$ & Eugenol & 1360 & 89.1 & 92.7 \\
$93-28-7$ & Eugenyl acetate & 1516 & 9.4 & 5.6 \\
$501-92-8$ & Chavicol & 1253 & 0.4 & 0.4 \\
$121-33-5$ & Vanilin & 1393 & 0.3 & 0.4 \\
$458-36-6$ & Coniferyl aldehyde & 1727 & 0.2 & 0.2 \\
$119-36-8$ & Methyl salicylate & 1189 & $<0.1$ & $<0.1$ \\
$87-44-5$ & (E)- $\beta$-Caryophyllene & 1417 & $<0.1$ & $<0.1$ \\
$6753-98-6$ & -Caryophyllene & 1451 & $<0.1$ & $<0.1$ \\
$120-51-4$ & Benzyl benzoate & 1764 & $<0.1$ & $<0.1$ \\
\hline
\end{tabular}

$\mathrm{H}_{\mathrm{HD} \_\mathrm{SPE}}$-hydrolate obtained by hydrodistillation and 50x concentrated using solid phase extraction (SPE); $\mathrm{H}_{\text {SD_SPE }}$-hydrolate obtained by steam distillation and $50 \times$ concentrated using SPE; RI-retention index relative to $n$-alkanes on SLB-5ms capillary column.

\subsection{Antimicrobial Activity of Hydrolates}

The antimicrobial activities of eight samples of non-concentrated and eight samples of concentrated hydrolates from Lavandula angustifolia Mill., Syzygium aromaticum L., Foeniculum vulgare Mill., and Laurus nobilis L. against eight strains of Arcobacter-like bacteria, and further against Staphylococcus aureus CCM 4223, Enterococcus faecalis CCM 4224, Pseudomonas aeruginosa CCM 3955, Escherichia coli CCM 3954 and the yeast Candida albicans CCM 8186, are presented in Tables 6 and 7. 
Table 6. Antimicrobial activity of hydrolates concentrated by SPE on Arcobacter-like strains-mean inhibition zones in mm (including disc 6 mm in diameter) \pm standard deviation and minimal inhibitory/bactericidal concentrations in $\%, n=4$.

\begin{tabular}{|c|c|c|c|c|c|c|c|c|c|c|}
\hline & & & $\begin{array}{c}A b \\
\text { LMG } 10828\end{array}$ & $\begin{array}{c}A b \\
\text { CCUG } \\
30484\end{array}$ & $\begin{array}{c}A b \\
\text { UPa } 2012 / 3\end{array}$ & $\begin{array}{c}A c \\
\text { CCM } 7050\end{array}$ & $\begin{array}{c}A c \\
\text { UPa 2013/13 }\end{array}$ & $\begin{array}{c}A l \\
\text { LMG } 28517\end{array}$ & $\begin{array}{c}A s \\
\text { LMG } 6621\end{array}$ & $\begin{array}{c}A t \\
\text { LMG } 24488\end{array}$ \\
\hline \multirow{4}{*}{ Lavender } & \multirow{2}{*}{ IZ } & $\mathrm{H}_{\mathrm{HD} \_\mathrm{SPE}}$ & $9.5 \pm 0.3$ & $8.8 \pm 0.3$ & $12.8 \pm 0.3$ & $8.3 \pm 0.5$ & $8.0 \pm 0$ & $11.3 \pm 1.0$ & $9.0 \pm 0.8$ & $11.5 \pm 0.3$ \\
\hline & & $\mathrm{H}_{\mathrm{SD} \_\mathrm{SPE}}$ & $10.8 \pm 0.3$ & $13.5 \pm 0.6$ & $10.5 \pm 0.3$ & $9.5 \pm 0.9$ & $11.5 \pm 0.1$ & $11.8 \pm 0.3$ & $10.3 \pm 0.5$ & $13.3 \pm 0.9$ \\
\hline & \multirow{2}{*}{$\begin{array}{l}\mathrm{MIC/} \\
\mathrm{MBC}\end{array}$} & $\mathrm{H}_{\text {HD_SPE }}$ & $0.4 / 0.8$ & $0.8 / 0.8$ & $0.8 / 1.6$ & $0.8 / 0.8$ & $0.8 / 0.8$ & $0.8 / 0.8$ & $0.4 / 0.4$ & $0.8 / 1.6$ \\
\hline & & $\mathrm{H}_{\mathrm{SD} \_\mathrm{SPE}}$ & $0.4 / 0.4$ & $0.4 / 0.8$ & $1.6 / 1.6$ & $0.4 / 0.8$ & $0.4 / 0.4$ & $0.4 / 0.8$ & $0.4 / 0.4$ & $0.4 / 0.8$ \\
\hline \multirow{4}{*}{ Fennel } & \multirow[b]{2}{*}{$\mathrm{IZ}$} & $\mathrm{H}_{\text {HD_SPE }}$ & $7.8 \pm 0.2$ & $9.0 \pm 0.8$ & $10.5 \pm 0.9$ & $9.8 \pm 0$ & $8.5 \pm 1.3$ & $10.8 \pm 0.5$ & $7.8 \pm 0.5$ & $12.0 \pm 0.1$ \\
\hline & & HSD_SPE & $10.8 \pm 0$ & $10.8 \pm 0.5$ & $10.8 \pm 0.9$ & $10.0 \pm 0.2$ & $10.0 \pm 0.8$ & $11.8 \pm 0$ & $10.3 \pm 0.3$ & $11.3 \pm 0.5$ \\
\hline & MIC/ & $\mathrm{H}_{\mathrm{HD}} \mathrm{SPE}$ & $1.6 / 1.6$ & $3.1 / 3.1$ & $1.6 / 3.1$ & $0.8 / 0.8$ & $1.6 / 1.6$ & $1.6 / 1.6$ & $0.8 / 0.8$ & $1.6 / 1.6$ \\
\hline & MBC & $\mathrm{H}_{\mathrm{SD} \_\mathrm{SPE}}$ & $0.8 / 1.6$ & $1.6 / 3.1$ & $1.6 / 1.6$ & $0.4 / 0.8$ & $0.8 / 0.8$ & $0.8 / 1.6$ & $0.4 / 0.4$ & $0.8 / 0.8$ \\
\hline \multirow{4}{*}{ Bay leaves } & \multirow{2}{*}{$\mathrm{IZ}$} & $\mathrm{H}_{\text {HD_SPE }}$ & $8.0 \pm 0.2$ & $9.0 \pm 0.8$ & $9.0 \pm 0$ & $9.5 \pm 0.3$ & $9.5 \pm 0.3$ & $11.3 \pm 0.3$ & $9.0 \pm 0.3$ & $10.8 \pm 0$ \\
\hline & & $\mathrm{H}_{\mathrm{SD} \_\mathrm{SPE}}$ & $10.5 \pm 0.3$ & $9.5 \pm 0.6$ & $14.0 \pm 0.8$ & $10.3 \pm 0.3$ & $10.0 \pm 0.3$ & $10.5 \pm 0.6$ & $12.5 \pm 0.7$ & $13.3 \pm 0.6$ \\
\hline & $\mathrm{MIC/}$ & $\mathrm{H}_{\mathrm{HD} \_S P E}$ & $1.6 / 1.6$ & $1.6 / 1.6$ & $1.6 / 3.1$ & $0.8 / 1.6$ & $0.8 / 1.6$ & $1.6 / 3.1$ & $1.6 / 3.1$ & $1.6 / 1.6$ \\
\hline & MBC & $\mathrm{H}_{\mathrm{SD} \_\mathrm{SPE}}$ & $0.8 / 1.6$ & $0.8 / 1.6$ & $0.8 / 1.6$ & $0.8 / 1.6$ & $0.8 / 1.6$ & $1.6 / 3.1$ & $1.6 / 1.6$ & $0.8 / 0.8$ \\
\hline \multirow{4}{*}{ Clove } & \multirow{2}{*}{$\mathrm{IZ}$} & $\mathrm{H}_{\text {HD_SPE }}$ & $10.5 \pm 0.3$ & $12.0 \pm 0.9$ & $13.0 \pm 0.6$ & $10.5 \pm 0.3$ & $14.3 \pm 0.5$ & $12.0 \pm 0.6$ & $12.0 \pm 0.9$ & $14.8 \pm 0.5$ \\
\hline & & $\mathrm{H}_{\mathrm{SD} \_\mathrm{SPE}}$ & $12.5 \pm 0.7$ & $13.5 \pm 0.4$ & $14.5 \pm 0.3$ & $12.5 \pm 0.3$ & $16.5 \pm 0.3$ & $12.8 \pm 0.7$ & $11.0 \pm 0.3$ & $15.5 \pm 0.7$ \\
\hline & MIC/ & $\mathrm{H}_{\mathrm{HD} \mathrm{SPE}}$ & $0.1 / 0.1$ & $0.2 / 0.2$ & $0.8 / 0.8$ & $0.2 / 0.2$ & $0.4 / 0.4$ & $0.4 / 0.4$ & $0.2 / 0.2$ & $0.4 / 0.4$ \\
\hline & MBC & $\mathrm{H}_{\mathrm{SD} \_\mathrm{SPE}}$ & $0.1 / 0.1$ & $0.1 / 0.1$ & $0.8 / 0.8$ & $0.1 / 0.1$ & $0.1 / 0.1$ & $0.4 / 0.4$ & $0.1 / 0.1$ & $0.2 / 0.4$ \\
\hline \multirow{2}{*}{ Control } & \multirow{2}{*}{\multicolumn{2}{|c|}{$\begin{array}{c}\mathrm{IZ} \\
\mathrm{MIC} / \mathrm{MBC}\end{array}$}} & $8.0 \pm 0.8$ & $7.7 \pm 0.5$ & $7.7 \pm 0.5$ & $8.0 \pm 0.8$ & $7.0 \pm 0.8$ & $6.7 \pm 0.5$ & $8.3 \pm 0.5$ & $8.0 \pm 0.8$ \\
\hline & & & $3.1 / 6.3$ & $3.1 / 6.3$ & $3.1 / 6.3$ & $1.6 / 3.1$ & $3.1 / 3.1$ & $3.1 / 3.1$ & $1.6 / 3.1$ & $3.1 / 3.1$ \\
\hline
\end{tabular}

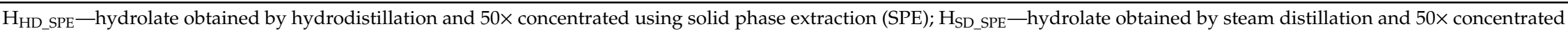
using SPE; Control—solvent without active compounds; IZ-inhibition zone; MIC—-minimal inhibitory concentration; MBC—minimal bactericidal concentration; $A b-A$. butzleri; $A c-A$. cryaerophilus; $A l-A$. lanthieri; As-A. skirrowii; At-A. thereius. 
Table 7. Antimicrobial activity of hydrolates concentrated by SPE on selected microorganisms-mean inhibition zones in $\mathrm{mm}$ (including disc $6 \mathrm{~mm}$ in diameter) \pm standard deviation or minimal inhibitory concentrations in $\%, n=4$.

\begin{tabular}{|c|c|c|c|c|c|c|c|}
\hline & & & $\begin{array}{c}S a \\
\text { CСM } 4223\end{array}$ & $\begin{array}{c}E f \\
\text { CCM } 4224\end{array}$ & $\begin{array}{c}P a \\
\text { CCM } 3955\end{array}$ & $\begin{array}{c}E c \\
\text { CСM } 3954\end{array}$ & $\begin{array}{c}C a \\
\text { CCM } 8186\end{array}$ \\
\hline \multirow{4}{*}{ Lavender } & \multirow[b]{2}{*}{$\mathrm{IZ}$} & $\mathrm{H}_{\mathrm{HD}} \mathrm{SPE}$ & $8.5 \pm 0.7$ & $7.5 \pm 0.6$ & $8.5 \pm 0.4$ & $8.8 \pm 0.5$ & $6.0 \pm 0$ \\
\hline & & $\mathrm{H}_{\mathrm{SD} \_\mathrm{SPE}}$ & $8.3 \pm 0.5$ & $9.5 \pm 0.3$ & $10.5 \pm 0.3$ & $9.0 \pm 0.3$ & $6.0 \pm 0$ \\
\hline & $\mathrm{MIC/}$ & $\mathrm{H}_{\mathrm{HD} \_S P E}$ & $1.6 / 3.1$ & $3.1 / 3.1$ & $1.6 / 3.1$ & $1.6 / 3.1$ & $6.3 / 6.3$ \\
\hline & $\mathrm{MBC}$ & $\mathrm{H}_{\mathrm{SD} \_\mathrm{SPE}}$ & $1.6 / 3.1$ & $1.6 / 3.1$ & $1.6 / 1.6$ & $1.6 / 3.1$ & $6.3 / 6.3$ \\
\hline \multirow{4}{*}{ Fennel } & \multirow{2}{*}{ IZ } & $\mathrm{H}_{\mathrm{HD} \_S P E}$ & $10.8 \pm 0.9$ & $9.3 \pm 0.9$ & $11.0 \pm 0.8$ & $11.3 \pm 0.5$ & $10.5 \pm 0.6$ \\
\hline & & $\mathrm{H}_{\mathrm{SD} \_\mathrm{SPE}}$ & $11.3 \pm 0.7$ & $15.0 \pm 0.1$ & $11.5 \pm 0.8$ & $11.5 \pm 0.3$ & $11.8 \pm 0.7$ \\
\hline & MIC/ & $\mathrm{H}_{\mathrm{HD}} \mathrm{SPE}$ & $3.1 / 6.3$ & $3.1 / 6.3$ & $3.1 / 3.1$ & $1.6 / 3.1$ & $1.6 / 3.1$ \\
\hline & $\mathrm{MBC}$ & $\mathrm{H}_{\mathrm{SD} \_\mathrm{SPE}}$ & $3.1 / 6.3$ & $1.6 / 3.2$ & $1.6 / 3.1$ & $1.6 / 3.1$ & $1.6 / 3.1$ \\
\hline \multirow{4}{*}{ Bay leaves } & \multirow{2}{*}{ IZ } & $\mathrm{H}_{\mathrm{HD} \_\mathrm{SPE}}$ & $9.5 \pm 0.3$ & $11.0 \pm 0.8$ & $10.3 \pm 0.7$ & $10.3 \pm 0.7$ & $9.8 \pm 0.9$ \\
\hline & & $\mathrm{H}_{\mathrm{SD} \_\mathrm{SPE}}$ & $9.5 \pm 0.6$ & $12.3 \pm 0.5$ & $11.5 \pm 0.9$ & $10.5 \pm 0.9$ & $13.3 \pm 0.9$ \\
\hline & $\mathrm{MIC/}$ & $\mathrm{H}_{\mathrm{HD} \_\mathrm{SPE}}$ & $1.6 / 1.6$ & $6.3 / 12.5$ & $1.6 / 3.1$ & $3.1 / 6.3$ & $1.6 / 3.1$ \\
\hline & MBC & $\mathrm{H}_{\text {SD_SPE }}$ & $1.6 / 1.6$ & $6.3 / 6.3$ & $3.1 / 6.3$ & $1.6 / 3.1$ & $0.4 / 0.8$ \\
\hline \multirow{4}{*}{ Clove } & \multirow{2}{*}{ IZ } & $\mathrm{H}_{\mathrm{HD} \_S P E}$ & $15.8 \pm 0.7$ & $15.3 \pm 0.3$ & $11.3 \pm 0.1$ & $13.5 \pm 0.7$ & $14.8 \pm 0.4$ \\
\hline & & $\mathrm{H}_{\text {SD_SPE }}$ & $15.5 \pm 0.9$ & $18.8 \pm 0.9$ & $12.8 \pm 0.7$ & $14.0 \pm 0.8$ & $23.5 \pm 0.7$ \\
\hline & $\mathrm{MIC/}$ & $\mathrm{H}_{\mathrm{HD} \_S P E}$ & $0.4 / 0.4$ & $0.8 / 0.8$ & $0.8 / 1.6$ & $3.1 / 6.3$ & $6.3 / 6.3$ \\
\hline & MBC & $\mathrm{H}_{\mathrm{SD} \_\mathrm{SPE}}$ & $0.4 / 0.8$ & $0.4 / 0.8$ & $0.4 / 0.8$ & $1.6 / 3.1$ & $1.6 / 3.1$ \\
\hline \multirow{2}{*}{ Control } & \multirow{2}{*}{\multicolumn{2}{|c|}{$\begin{array}{c}\mathrm{IZ} \\
\mathrm{MIC} / \mathrm{MBC}\end{array}$}} & $7.3 \pm 0.5$ & $9.0 \pm 0.8$ & $8.7 \pm 0.5$ & $8.0 \pm 0$ & $6.3 \pm 0.5$ \\
\hline & & & $12.5 / 12.5$ & $12.5 / 12.5$ & $3.1 / 6.3$ & $6.3 / 12.5$ & $6.3 / 12.5$ \\
\hline
\end{tabular}

$\mathrm{H}_{\mathrm{HD} \text { SPE }}$ - hydrolate obtained by hydrodistillation and 50x concentrated using solid phase extraction (SPE); $\mathrm{H}_{\mathrm{SD} \_\mathrm{SPE}}$-hydrolate obtained by steam distillation and 50x concentrated using SPE; Control—solvent without active compounds; IZ-inhibition zone; MIC—-minimal inhibitory concentration; MBC—-minimal bactericidal concentration; $\mathrm{Sa}-\mathrm{S}$. aureus; $\mathrm{Ef}-\mathrm{E}$. faecalis; $\mathrm{Pa}-\mathrm{P}$. aeruginosa; Ec-E. coli; $\mathrm{Ca}-\mathrm{C}$. albicans.

\subsubsection{Non-Concentrated Hydrolate $\left(\mathrm{H}_{\mathrm{HD}}, \mathrm{H}_{\mathrm{SD}}\right)$}

For most of the tested hydrolates $\mathrm{H}_{\mathrm{HD}}$ and $\mathrm{H}_{\mathrm{SD}}$, no antimicrobial activity against the observed microorganisms was recorded. For this reason, the data are not presented in the form of a table. Most of the studied arcobacters were not suppressed by non-concentrated hydrolates at all. However, a very weak antimicrobial activity of clove hydrolate was reported just against $A$. thereius LMG $24488\left(\mathrm{H}_{\mathrm{HD}}\right.$, inhibition zone $6.5 \pm 0.3 \mathrm{~mm}$; $\mathrm{H}_{\mathrm{SD}}$, inhibition zone $\left.6.8 \pm 0.4 \mathrm{~mm}\right)$. None of the tested arcobacters were suppressed by the hydrolates obtained by the distillation of lavender, fennel and laurel.

According to our results, weak antimicrobial activity on other Gram-negative (Ps. aeruginosa, E. coli) bacteria was observed only in the case of clove hydrolate, in the range of inhibition zones 7.0-7.3 mm. In general, Gram-negative bacteria are more resistant to, e.g., EOs than Gram-positive bacteria, mainly due to the composition of the cell wall [39]. In the case of Gram-positive (S. aureus, Ent. faecalis) bacteria, the weak antibacterial activity of all monitored hydrolates was observed. The highest antimicrobial activity on Gram-positive bacteria was observed in the case of fennel and clove hydrolates. In S. aureus CCM 4223, with fennel or clove $\mathrm{H}_{\mathrm{HD}} / \mathrm{H}_{\mathrm{SD}}$, inhibition zones of $8.0 / 8.0$ and $7.8 / 8.3 \mathrm{~mm}$ were observed, respectively. Similar antimicrobial effects of fennel EO and extract have also been reported in earlier publications [40,41]. The Ent. faecalis CCM 4224 strain was most inhibited by bay leaf $\left(\mathrm{H}_{\mathrm{HD}}, 7.8 \pm 1.3 ; \mathrm{H}_{\mathrm{SD}}, 7.8 \pm 0.5 \mathrm{~mm}\right)$, fennel $\left(\mathrm{H}_{\mathrm{HD}}, 7.8 \pm 0.5 ; \mathrm{H}_{\mathrm{SD}}, 7.8 \pm 0.5 \mathrm{~mm}\right)$ and clove $\left(\mathrm{H}_{\mathrm{HD}}, 7.5 \pm 0.5 ; \mathrm{H}_{\mathrm{SD}}, 7.5 \pm 0.6 \mathrm{~mm}\right)$ hydrolates. It has been previously reported that clove $\mathrm{EO}$ also exhibits significant inhibitory effects against Ps. aeruginosa, S. aureus and E. coli [42].

Although linalool as a pure chemical has been demonstrated [43] to be a potent antimicrobial agent against a wide range of microorganisms, except Pseudomonas aeruginosa, its higher percentage did not give the expected results for HD hydrolate extract in the antimicrobial assay. Coumarin 
and its derivatives have been evaluated as having potentially broad antimicrobial activity [44,45]. In combination with the relatively high differences in linalool derivative content, this may be one of the causes of the higher antimicrobial activity of $\mathrm{H}_{\mathrm{SD}}$ extracts (see Table 6). It was previously reported that the high linalool content or its addition to an EO significantly increases its antimicrobial effects [46]. A greater antimicrobial effect of the laurel-derived hydrolate against Gram-positive bacteria has been reported in the literature [47]. However, this has not been unequivocally confirmed in our study. C. albicans CCM 8186 was not inhibited by the tested hydrolates at all.

The obtained results show that the prepared non-concentrated hydrolates do not have significant antimicrobial potential against the tested microorganisms. The antimicrobial activity of hydrolates is also significantly influenced by the method used to obtain the distilled matrices $[11,13,48]$. There is limited information in the literature about the antimicrobial effects of hydrolates, but many studies describe the antimicrobial activity of EOs. The greater antimicrobial activity of EOs is mainly due to the higher concentration of the main essential components. Importantly, even the hydrolates obtained by distillation still have antimicrobial activity [49], and may thus be further used, especially in their concentrated form.

\subsubsection{Concentrated Hydrolate ( $\left.\mathrm{H}_{\mathrm{HD}} \mathrm{SPE}, \mathrm{H}_{\mathrm{SD} \_\mathrm{SPE}}\right)$}

In contrast, concentrated hydrolates exhibited significant antimicrobial activity (see Tables 6 and 7) with inhibition zones up to $23.5 \mathrm{~mm}$ in diameter and minimal inhibitory (bactericidal) concentration up to $0.1 \%$. The inhibitory effect of concentrated hydrolates may be partially due to the presence of extraction reagent (ethanol). The influence of ethanol on the resulting inhibitory activity of the concentrated hydrolates was, of course, also evaluated. The antimicrobial activity of ethanol is presented in Tables 6 and 7; however, the inhibition zones of the pure solvent were only recorded in the range of 6.3-9 $\mathrm{mm}$ (MIC in the range 1.6-12.5\%), depending on the strain tested.

Significant inhibition was observed in the presence of concentrated hydrolates $\mathrm{H}_{\mathrm{HD}} \mathrm{SPE}$ and $\mathrm{H}_{\mathrm{SD} \_\mathrm{SPE}}$. Overall, the minimum inhibitory concentrations of all monitored samples in the range of $0.1-6.3 \%$ were found. In the vast majority of cases, the MIC and MBC values were the same or lower. However, in general, most of the hydrolates obtained by steam distillation showed higher antimicrobial activities compared to hydrolates obtained by hydrodistillation. Both concentrated clove hydrolates exhibited the highest antimicrobial activity of all the matrices tested. Clove is a very rich source of various antimicrobials [50]. In addition, according to our results, a significant content of eugenol and eugenyl acetate was observed in clove hydrolates. The lowest minimum inhibitory concentrations, in the range of just $0.1-0.8 \%$, were measured for clove hydrolate, and can be considered essentially the most antimicrobially effective.

Lavender $\mathrm{H}_{\mathrm{SD}}$ SPE had the strongest antimicrobial activity against A. butzleri CCUG 30484 and $A$. thereius LMG 24488 (13.5 \pm 0.6 and $13.3 \pm 0.9 \mathrm{~mm}$ inhibition zones, respectively). On the contrary, the growth of the A. butzleri UPa 2012/3 strain was more inhibited by lavender $\mathrm{H}_{\mathrm{HD} \_S P E}$ (inhibition zone $12.8 \pm 0.3 \mathrm{~mm}$ ). The antimicrobial effects of both lavender $\mathrm{EO}$ and hydrolate have also been previously described in the literature [7,51,52]. Overall, the most sensitive Arcobacter-like strain tested was A. cryaerophilus UPa 2013/13, in which an inhibition zone of $16.5 \pm 0.3 \mathrm{~mm}$ was recorded for clove $\mathrm{H}_{\mathrm{SD} S \mathrm{SPE}}$. The $A$. butzleri UPa 2012/3 strain was the most sensitive to laurel and clove $\mathrm{H}_{\mathrm{SD} \_S P E}$ (inhibition zones $14.0 \pm 0.8$ and $14.5 \pm 0.3 \mathrm{~mm}$, respectively). The highest resistance of arcobacters was observed especially in relation to fennel hydrolate.

Both concentrated hydrolates ( $\mathrm{H}_{\mathrm{HD}}$ SPE and $\mathrm{H}_{\mathrm{SD}}$ SSPE$)$ were almost comparable in antimicrobial activity against Gram-positive $S$. aureus CCM 4223. The lowest inhibitory activities were observed with lavender-derived hydrolates, then laurel and fennel, and the greatest antimicrobial effect was determined with clove hydrolate, with inhibition zones up to $15.8 \mathrm{~mm}$ and MIC at $0.4 \%$. In Ent. faecalis CCM 4224, an inhibition zone of $15.0 \pm 0.1 \mathrm{~mm}$ was observed for fennel $\mathrm{H}_{\mathrm{SD} \_\mathrm{SPE}}$. This is possibly due to the higher estragole and $p$-methoxy cinnamaldehyde content in $\mathrm{H}_{\mathrm{SD}} \mathrm{SPE}$ compared to $\mathrm{H}_{\mathrm{HD}} \mathrm{SPE}$ with lower antimicrobial activity. Conversely, however, fennel $\mathrm{H}_{\mathrm{HD} \_\mathrm{SPE}}$ has a higher content of eugenol 
and eugenyl acetate, which are known to have high antimicrobial potential [53]. E. coli was most suppressed by clove hydrolates (inhibition zone $13.5 \pm 0.7$ and $14.0 \pm 0.8 \mathrm{~mm}$ ).

C. albicans CCM 8186 was not inhibited even by concentrated lavender hydrolates in the case of the disk diffusion test; however, the minimal inhibitory concentration was $6.3 \%$. In contrast, the growth of $C$. albicans was suppressed by laurel HSD_SPE $(13.3 \pm 0.9 \mathrm{~mm}$ inhibition zone; MIC $0.4 \%)$. It has been previously reported that laurel hydrolates have significant antifungal activity [54]. However, clove $\mathrm{H}_{\mathrm{SD} \_S P E}$ was the most effective against $C$. albicans $\mathrm{CCM} 8186$ yeast (inhibition zone $23.5 \pm 0.7 \mathrm{~mm}$; MIC 1.6\%). Antimicrobial and antifungal effects have already been described in eugenol, the main aromatic component of cloves $[8,53,55,56]$. The antimicrobial effect of clove hydrolate appears to be supported, inter alia, by the eugenyl acetate content, which is higher than in the $\mathrm{H}_{\mathrm{SD} \_ \text {sPE }}$, and in which a higher antimicrobial effect was also observed compared to the $\mathrm{H}_{\mathrm{HD} \_\mathrm{SPE}}$. It has previously been reported in the literature that the incorporation of acetate into a molecule may increase the antimicrobial effect [57].

Table 8 shows, for comparison, the inhibitory effects of common antimicrobials against the microorganisms involved in this study. Based on the comparison of the inhibition zones of antibiotics/antifungals and the monitored samples (Tables 6 and 7), it is evident that the antimicrobial effect of antibiotics is higher. However, it is also necessary to look for suitable alternatives to antimicrobial substances in purely natural materials [58]. The EOs, as natural extracts, and the hydrolates obtained as by-products (with low adverse effects) may also become reliable alternatives in antimicrobial therapy.

Table 8. Testing the effectiveness of antibiotics and antifungals (mean inhibition zones in $\mathrm{mm}$, including disc $6 \mathrm{~mm}$ in diameter \pm standard deviation), $n=4$.

\begin{tabular}{|c|c|c|c|c|c|c|}
\hline & AMP & CIP & DA & $\mathbf{E}$ & TE & FCA \\
\hline A. butzleri CCUG 30484 & $6.0 \pm 0$ & $43.5 \pm 2.1$ & $7.5 \pm 0.7$ & $37.5 \pm 0.7$ & $31.5 \pm 2.1$ & n.t. \\
\hline A. butzleri LMG 10828 & $6.0 \pm 0$ & $34.5 \pm 0.7$ & $6.0 \pm 0$ & $23.0 \pm 0$ & $16.0 \pm 0$ & n.t. \\
\hline A. butzleri UPa 2012/3 & $6.0 \pm 0$ & $39.0 \pm 1.4$ & $6.0 \pm 0$ & $29.0 \pm 1.4$ & $24.0 \pm 1.4$ & n.t. \\
\hline A. cryaerophilus CCM 7050 & $6.0 \pm 0$ & $25.0 \pm 0$ & $6.0 \pm 0$ & $31.5 \pm 0.7$ & $27.5 \pm 0.7$ & n.t. \\
\hline A. cryaerophilus UPa 2013/13 & $6.0 \pm 0$ & $36.5 \pm 0.7$ & $6.0 \pm 0$ & $30.5 \pm 0.7$ & $29.0 \pm 1.4$ & n.t. \\
\hline A. lanthieri LMG 28517 & $6.0 \pm 0$ & $37.0 \pm 1.4$ & $6.0 \pm 0$ & $22.0 \pm 2.8$ & $17.5 \pm 0.7$ & n.t. \\
\hline A. skirrowii LMG 6621 & $6.0 \pm 0$ & $41.0 \pm 1.4$ & $23.0 \pm 2.8$ & $30.0 \pm 0$ & $34.0 \pm 2.8$ & n.t. \\
\hline A. thereius LMG 24488 & $6.0 \pm 0$ & $32.5 \pm 0.7$ & $35.5 \pm 0.7$ & $11.0 \pm 0$ & $35.0 \pm 0$ & n.t. \\
\hline S. aureus CCM 4232 & $27.0 \pm 0$ & $25.5 \pm 0.5$ & $27.0 \pm 1.4$ & $28.0 \pm 2.8$ & $14.5 \pm 0.7$ & n.t. \\
\hline E. faecalis CCM 4224 & $13.0 \pm 0$ & $22.0 \pm 0$ & $7.0 \pm 0$ & $17.5 \pm 0.7$ & $29.0 \pm 1.4$ & n.t. \\
\hline P. aeruginosa CCM 3955 & $6.0 \pm 0$ & $34.0 \pm 1.4$ & $6.0 \pm 0$ & $8.5 \pm 0.7$ & $13.5 \pm 0.7$ & n.t. \\
\hline E. coli CCM 3954 & $6.0 \pm 0$ & $31.0 \pm 1.4$ & $6.0 \pm 0$ & $9.5 \pm 0.7$ & $20.5 \pm 0.7$ & n.t. \\
\hline C. albicans CCM 8186 & n.t. & n.t. & n.t. & n.t. & n.t. & $16.0 \pm 1.4$ \\
\hline
\end{tabular}

\subsection{Biofilm Activity of Selected Microorganisms in the Presence of Hydrolate}

The characterization of new potential antimicrobial agents is important, inter alia, in terms of the increasing resistance of microorganisms. In this respect, the inhibition of not only planktonic cells but also biofilm formation is often important [59]. The bacteria in a biofilm are more resistant and are more difficult to remove from surfaces than planktonic cells [60,61]. The biofilm formations of $A$. butzleri CCUG 30484, A. cryaerophilus CCM 7050, A. lanthieri LMG 28517, A. thereius LMG 24488, S. aureus CCM 4223 and E. coli CCM 3954 were studied in the presence of prepared hydrolates before and after increasing their concentration. The results are shown in Figure 1, which shows the different values of biofilm activity that also depended on the preparation method of the given hydrolate $\left(\mathrm{H}_{\mathrm{HD}} \mathrm{vs}\right.$. $\left.\mathrm{H}_{\mathrm{SD}}\right)$. Most of the natural concentrated hydrolates obtained by hydrodistillation showed a higher antibiofilm effect (see Figure 1b). However, a higher antimicrobial effect on planktonic cells was observed for hydrolates obtained by steam distillation. This could probably be explained by the fact that the higher antimicrobial efficacy of some substances (under certain circumstances) may induce an increased biofilm formation activity of microorganisms. The effects on biofilm structures may often not be as 
significant as in the case of planktonic cells. This may depend, for example, on the cellular metabolic activity, and the amount of extracellular polymer matrix in the biofilm structure [62], and increased biofilm formation can also be considered when exposed to substances with a higher antimicrobial effect.
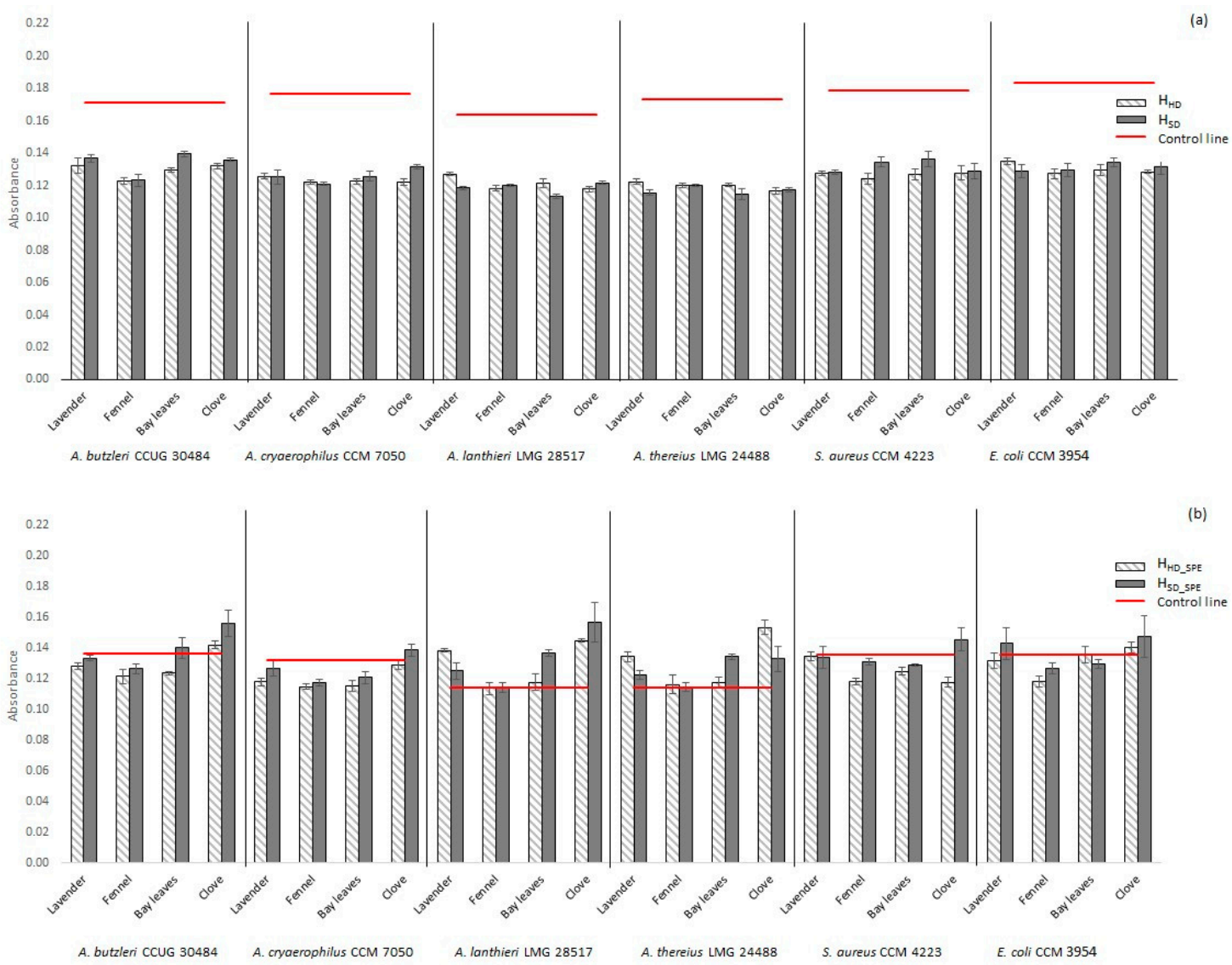

Figure 1. Biofilm formation in the presence of non-concentrated hydrolates (a) and concentrated hydrolates (b). Bars represent standard deviation, $n=3 . \mathrm{H}_{\mathrm{HD}}$-hydrolate obtained by hydrodistillation; $\mathrm{H}_{\mathrm{SD}}$ - hydrolate obtained by steam distillation; $\mathrm{H}_{\mathrm{HD} \_\mathrm{SPE}}$ - hydrolate obtained by hydrodistillation and $50 \times$ concentrated using solid phase extraction (SPE); $\mathrm{H}_{\mathrm{SD} \_\mathrm{SPE}}$-hydrolate obtained by steam distillation and $50 \times$ concentrated using SPE. Red lines_-biofilm formation of strains in water (a), biofilm formation of strains in extraction solvent (b); values above/below the red lines-increased/reduced biofilm formation due to hydrolate presence.

According to our preliminary testing, all microbial strains used can be considered biofilm-positive. The biofilm formation of all tested strains was reduced in the environment of the prepared hydrolates in contrast to the amount of biofilm formed in water without the presence of hydrolates (see Figure 1a, red line). Some strains exhibited a significant decrease in the amount of biofilm formed in the presence of non-concentrated hydrolates, e.g., A. thereius (by up to 35.9\%) and A. lanthieri (by up to $31.0 \%$ ) in the case of the $\mathrm{H}_{\mathrm{SD} \_\mathrm{SPE}}$ of bay leaves hydrolate. On the other hand, a slightly reduced biofilm activity was determined in the case of, e.g., A. butzleri (by up to $18.7 \%$ in the case of the $\mathrm{H}_{\mathrm{SD} \_ \text {SPE }}$ of bay leaves). In agreement with this, a significant antibiofilm effect of, e.g., lavender and clove EOs is described in the literature [63], which is associated with a significantly higher content of individual active substances. Previously, there has also been a mention in the literature of the antibiofilm activities of, e.g., lavender and oregano with S. aureus [63].

Significantly different results were obtained in the presence of concentrated hydrolates. In the case of concentrated hydrolates, increased biofilm formation was found in some tested strains compared to the amount of biofilm formed in the extraction solvent alone (see Figure 1b, red line). In the A. thereius LMG 24488 strain, an increase in biofilm formation was observed even in the environment of the 
concentrated samples (except for the fennel hydrolates). A rapid increase in biofilm activity was also observed in the clove $\mathrm{H}_{\mathrm{SD} \_} \mathrm{SPE}$ environment for A. lanthieri LMG 28517 and $\mathrm{H}_{\mathrm{HD} \text { _SPE }}$ for A. thereius LMG 24488. Clove $\mathrm{H}_{\mathrm{SD} \text { SPE }}$ also contains approximately twice the amount of eugenyl acetate (see Table 5), which could affect biofilm formation in these bacteria. However, the increased biofilm formation in the presence of hydrolates obtained from Syzygium aromaticum can be explained by the very severe stress effect. The matrix contains a considerable amount of antimicrobial agents, however the natural protective function of some microorganisms is the formation of a biofilm structure [64]. Biofilm structure is largely protected from external influences and microorganisms are more resistant. Clove hydrolate has been shown to be more antimicrobially effective against planktonic cells (Table 6), but bacteria often respond to the significant inhibitory effect of bacteria by increasing and rapid biofilm formation. Clove hydrolate contains a high proportion of eugenol (see Table 5), for which an antibiofilm effect has been previously described [65]. However, it certainly depends on the amount of the substance and also on the specific case of the microbial strain, as also stated in the publication.

However, the biofilm activity of A. butzleri CCUG 30484, A. cryaerophilus CCM 7050, and S. aureus CCM 4223 was reduced (in comparison with other strains and clove hydrolates) in the concentrated lavender, fennel, and bay leaves hydrolate environments (see Figure 1b). EO components are known to significantly reduce biofilm activity [66]. Further studies have shown that farnesol induces a decrease in biofilm production [67]. The presence of farnesol was observed in the lavender hydrolate in our study, but only at a low concentration (see Table 4), but still obviously with an interesting antibiofilm activity.

Plant EOs have an antimicrobial potential that can be used to suppress microorganisms [68]. As far as we know, the effect of natural hydrolates on biofilm formation activity has not yet been well described. According to the results of our study, hydrolates also appear to be useful in this regard. However, it has been previously reported that, for example, coriander EO and its main component (linalool) have been able to inhibit the production of a microbial biofilm in vitro [69]. Furthermore, the inhibition of the biofilm production of uropathogens (E. coli, Ps. aeruginosa, Proteus mirabilis and Serratia marcescens) by curcumin has been reported. It has also been documented that curcumin generally increases the sensitivity of some strains to antibiotics [70].

\subsection{In Vitro Cytotoxicity of Hydrolates}

The cytotoxic level of medicinal plants or potential natural compounds must also be evaluated against host cells in the case of medical use or other applications [71]. The cytotoxicity of the hydrolates concentrated by SPE was analyzed using the xCELLigence system against the human lung carcinoma (A549) cells. It was observed that A549 cells treated with determined minimal inhibitory concentrations against microorganisms- $0.4 \%$ of lavender $\mathrm{H}_{\mathrm{HD} \_ \text {SPE }}$ and of lavender $\mathrm{H}_{\mathrm{SD} \_\mathrm{SPE}}, 0.8 \%$ of fennel $\mathrm{H}_{\mathrm{HD} \_\mathrm{SPE}}, 0.4 \%$ of fennel $\mathrm{H}_{\mathrm{SD} \_\mathrm{SPE}}, 0.8 \%$ of bay leaves $\mathrm{H}_{\mathrm{HD} \_\mathrm{SPE}}, 0.4 \%$ of bay leaves $\mathrm{H}_{\mathrm{SD} \_\mathrm{SPE}}$ and $0.1 \%$ of clove $\mathrm{H}_{\mathrm{HD} \_\mathrm{SPE}}$ and $\mathrm{H}_{\mathrm{SD} \_\mathrm{SPE}}$-were proliferating in parallel with cells treated with vehicle control, as indicated by the increase in CI values (Figure 2). This showed that A549 cell growth was not affected, thus suggesting the negligible cytotoxicity of the concentrated hydrolates tested in this study. Several studies also describing the cytotoxicity of lavender, laurel, fennel and other extracts have been published in the past [72-74], and the results suggest the utility of these natural matrices for many other applications. 

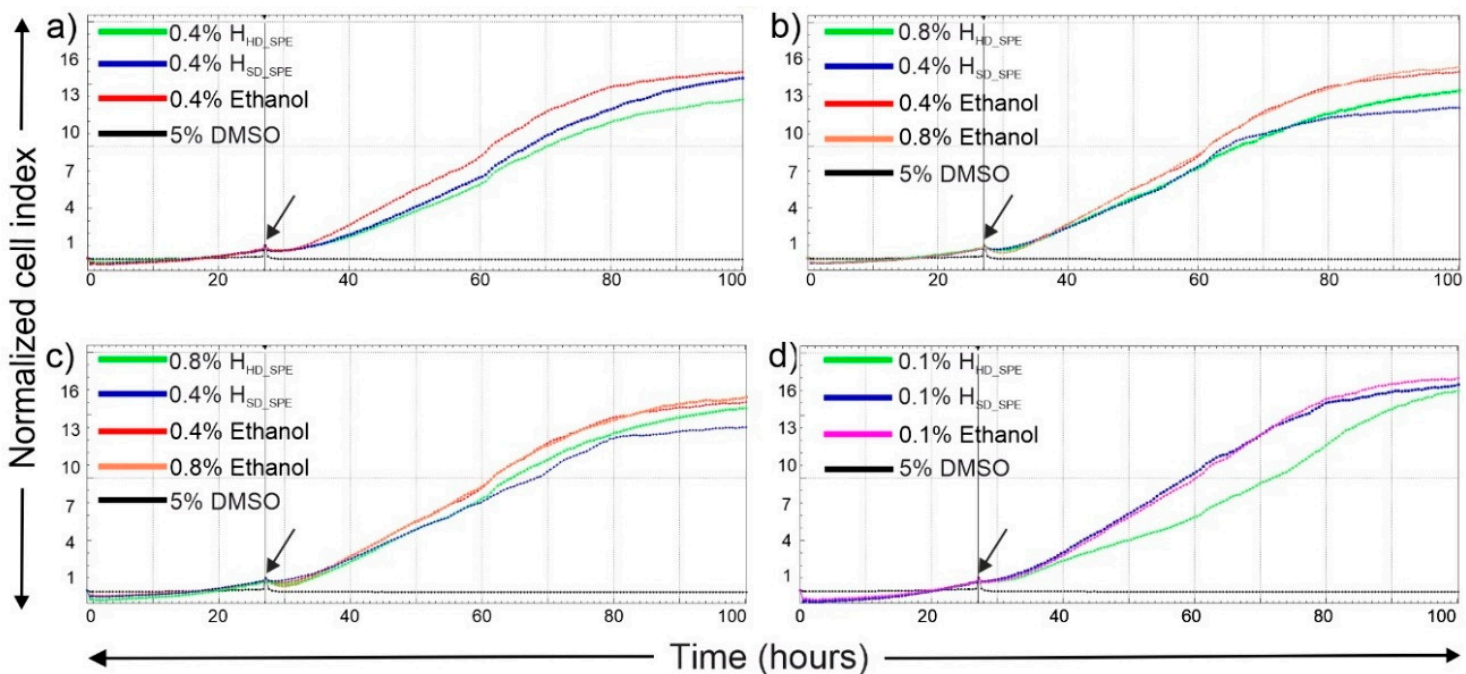

Figure 2. Dynamic monitoring of cytotoxic response to different concentrations of the hydrolates concentrated by SPE. A549 cells were treated with selected concentrations of (a) lavender, (b) fennel, (c) bay leaves and (d) clove concentrated hydrolates. Cells treated with $0.1 \%, 0.4 \%$ and $0.8 \%$ ethanol were used as vehicle control and 5\% DMSO treated cells were as positive control. Arrow showing time-point of treatment. Cell index values over 72 consecutive treatment hours were normalized to the time point of treatment.

\section{Materials and Methods}

\subsection{Plant Materials and Sample Preparation}

Plant material was bought from the following distributors: Lavandula angustifolia Mill.-lavender buds, origin-Croatia (Mediate, Libchavy, Czech Republic); Laurus nobilis L.—bay leaves, origin-Brazil (Kasia Vera, Říčany, Czech Republic); Syzygium aromaticum L.—clove buds, origin-Madagascar (Kasia Vera, Ř́čany, Czech Republic) and Foeniculum vulgare Mill.-fennel seeds, origin-Czech Republic (Kasia Vera, Ǩíčany, Czech Republic).

Prior to the analysis, samples were preserved in the dark at laboratory temperature. Before the distillation, bay leaves were cut into small pieces of ca. $0.5 \times 0.5 \mathrm{~cm}$. Hydrolates were obtained by hydrodistillation (HD) and steam distillation (SD). Each experiment was performed in triplicate.

\subsubsection{Steam Distillation}

Steam distillation was performed in a steam distillation system. The distillation flask was connected to a cylindrical body containing the plant material. The hydrolate was prepared as follows: the appropriate amount of plant material was weighed into the cylindrical body. Then, $1500 \mathrm{~mL}$ of deionized water was placed into the $2000 \mathrm{~mL}$ distillation flask (water was refilled as needed) and the distillation was started. The EO and hydrolate were collected in a separator with an outlet for the hydrolate (the hydrolate was collected in a dark flask during the distillation). The distillation was finished when the amount of obtained essential oil remained constant. After distillation, the rest of the hydrolate was separated from the essential oil, put into the dark flask and stored at $4{ }^{\circ} \mathrm{C}$. The final sample of hydrolate was obtained by mixing the hydrolates from three distillation runs.

\subsubsection{Hydrodistillation}

Hydrodistillation was performed in the hydrodistillation system. The hydrolate was prepared as follows: the appropriate amount of plant material was weighed into a $2000 \mathrm{~mL}$ distillation flask, $500 \mathrm{~mL}$ of deionized water was added (water was replenished during the distillation) and the distillation was 
started. The hydrolate was collected as described in Section 3.1.1. The final sample of hydrolate was obtained by mixing the hydrolates from three distillation runs.

\subsection{Solid Phase Extraction (SPE)}

After obtaining the hydrolates $\left(\mathrm{H}_{\mathrm{SD}}\right.$ or $\left.\mathrm{H}_{\mathrm{HD}}\right)$, they were $50 \times$ concentrated using Separon SGX C18 (modified octadecylsilicagel, $60 \mu \mathrm{m}, 0.5 \mathrm{~g}$ ) into a 96\% ethanol. The sorbent in the column was activated with $5 \mathrm{~mL}$ of methanol, and finally rinsed with $10 \mathrm{~mL}$ of sterile distilled water. Then $100 \mathrm{~mL}$ of hydrolate was passed through the column using a syringe, after which the compounds were eluted from the sorbent using $2 \mathrm{~mL}$ of ethanol solvent. The extract obtained by SPE from hydrolates is called an $\mathrm{H}_{\mathrm{SD} \_ \text {SPE }}$ or $\mathrm{H}_{\mathrm{HD} \_ \text {SPE }}$ extract within the text.

\subsection{Antimicrobial Testing}

The microorganisms used in this study were as follows-A. butzleri LMG 10828, A. butzleri CCUG 30484, A. butzleri UPa 2012/3, A. cryaerophilus CCM 7050, A. cryaerophilus UPa 2013/13, A. lanthieri LMG 28517, A. skirrowii LMG 6621, A. thereius LMG 24488, S. aureus CCM 4223, Ent. faecalis CCM 4224, Ps. aeruginosa CCM 3955, E. coli CCM 3954, and C. albicans CCM 8186. Strains were purchased from the Czech Collection of Microorganisms (CCM, Brno, Czech Republic), Culture Collection University of Göteborg (CCUG, Göteborg, Sweden), and Belgian Co-ordinated Collections of Microorganisms (LMG, Ghent, Belgium), and were isolated at the University of Pardubice (UPa, Pardubice, Czech Republic).

The antimicrobial activity of hydrolates (from steam distillation and hydrodistillation) obtained from lavender, bay leaves, clove, and fennel was tested. The disc diffusion method was used to determine the susceptibility of the strain to the hydrolates. A cell suspension with turbidity according to the McFarland scale were freshly prepared corresponding to the grade $0.5\left(\sim 1.5 \times 10^{8} \mathrm{CFU} \cdot \mathrm{mL}^{-1}\right)$. The microbial cell suspension was spread onto Mueller-Hinton agar (MHA; Himedia, India) or Sabouraud dextrose agar (Himedia, India) plates using a sterile cotton swab. Sterile discs of $6 \mathrm{~mm}$ in diameter (Oxoid Ltd., UK) were impregnated with $8 \mu \mathrm{L}$ of the tested sample (or ethanol as a control). After cultivation at $30^{\circ} \mathrm{C}$ (Arcobacter-like bacteria) or $37^{\circ} \mathrm{C}$ (other microbes), the diameter of the inhibition zone was evaluated using a BACMED 6iG2 automated reader and analyzer (Aspiag, Litomyšl, Czech Republic). Commercial antimicrobial discs (Sigma-Aldrich, St. Louis, MO, USA) were used as a reference standard of antimicrobial activity-ampicillin $(10 \mu \mathrm{g})$, ciprofloxacin $(5 \mu \mathrm{g})$, clindamycin $(2 \mu \mathrm{g})$, erythromycin $(15 \mu \mathrm{g})$, fluconazole $(25 \mu \mathrm{g})$, and tetracycline $(30 \mu \mathrm{g})$. Each experiment was performed at least in triplicate, and the displayed inhibition zones are expressed as a mean of inhibition zones with standard deviation.

Minimal inhibitory concentration (MIC) was determined by a microdilution method in 96-well microtiter plates (SPL Life Sciences, Pocheon-si, South Korea). Hydrolates in Mueller-Hinton broth (MHB; Himedia, India) at concentrations of $0.02-50 \%$ were evaluated in a final volume of $100 \mu \mathrm{L}$ in each well. The wells were inoculated with a microorganism suspension at a density of $1.5 \times 10^{6}$ $\mathrm{CFU} \cdot \mathrm{mL}^{-1}$. After cultivation, MIC was detected by lack of visual turbidity. For the evaluation of minimal bactericidal concentration (MBC), the content of each well was sub-cultured on Mueller-Hinton agar or Sabouraud dextrose agar. MBC was stated as the lowest concentration of the hydrolate that completely inhibited the growth of microorganisms (99.9\%) in CFU. $\mathrm{mL}^{-1}$. Each experiment was performed at least in triplicate, and the displayed concentrations are expressed as a mean.

\subsection{Biofilm Formation Determination}

Biofilm formation in the presence of hydrolates obtained from lavender, bay leaves, clove, and fennel was monitored in flat-bottomed microtiter plates (SPL Life Sciences, Pocheon-si, South Korea) as previously described by Silhova-Hruskova [75], with modifications. Briefly, the strain cultured in brain heart infusion broth (BHI; Himedia, India) was prepared at a final cell concentration of $10^{7} \mathrm{CFU} \cdot \mathrm{mL}^{-1}$. After incubation at $30{ }^{\circ} \mathrm{C}$ for $24 \mathrm{~h}$ under aerobic conditions, the microtiter plate was washed with 
sterile distilled water and dried. Biofilm fixation was performed with $2 \%$ sodium acetate (15 min) and biofilm-forming cells were stained with $100 \mu \mathrm{L}$ of $1 \%$ crystal violet (Sigma-Aldrich, St. Louis, MO, USA). After 15 min of staining, the plate was repeatedly washed and dried. Thereafter, the biofilm-associated violet was solubilized with $96 \%$ ethanol and the absorbance of the solution was measured in a new plate at $595 \mathrm{~nm}$ (Infinite M200, Tecan, Männedorf, Switzerland).

In addition, the influence of ethanol (used for SPE concentration of hydrolates) was monitored in order to determine the real effect of the tested hydrolates on biofilm formation, as ethanol also affects biofilm activity. The experiments were performed as above, but just in the presence of ethanol. The biofilm formation in the presence of ethanol is presented by red lines in Figure $1 b$.

There were 8 wells in each experiment, and the experiments were independently repeated three times. The obtained values were statistically evaluated using Excel 2010 (Microsoft, Redmond, WA, USA) and Statistica 12 (StatSoft, Tulsa, OK, USA). Extreme values were tested with the Dean-Dixon test, and all remoteness values were excluded with 95\% probability. Median and standard deviations were determined from the remaining values. A possible source of error resulting from insufficient dye washing, and resulting in an increase in absorbance, was also considered, and absorbance values that were too high compared to other measured values were excluded.

\subsection{GC-MS Analysis}

GC-MS analysis of the obtained extracts was carried out with a GC 2010 Gas Chromatograph, GCMS-QP2010 Plus Mass Selective Detector (both Shimadzu, Kyoto, Japan) and Combi Pal Autosampler (CTC Analytics, AG, Zwingen, Swizerland). The GC was equipped with an SLB-5ms capillary column (30 m $\times 0.25 \mathrm{~mm}, 2.5 \mu \mathrm{m}$ film thickness; Supelco, Bellefonte, PA, USA). Helium 5.0 (Linde, Praha, Czech Republic) was used as the carrier gas at a constant flow rate of $30 \mathrm{~cm} \cdot \mathrm{s}^{-1}$. The GC oven temperature was programmed as follows: initial temperature of $40{ }^{\circ} \mathrm{C}$ for $3 \mathrm{~min}$, then heated up to $250{ }^{\circ} \mathrm{C}$ at $2{ }^{\circ} \mathrm{C} \cdot \mathrm{min}^{-1}$. The injector temperature was set to $200^{\circ} \mathrm{C}$. Then, $1 \mu \mathrm{L}$ of extract was injected with a split ratio of 1:50. Mass spectrometry was run in electron ionization mode (EI) at $70 \mathrm{eV}$, in which ions with $\mathrm{m} / \mathrm{z} 33-500$ were scanned. Ion source and interface temperatures were set to $200{ }^{\circ} \mathrm{C}$.

Mass spectral identification was performed by comparing mass spectra with the commercial mass spectral databases NIST'14 Mass Spectral Library and FFNSC library (GC-MS Flavor \& Fragrance Natural \& Synthetic Compounds Library). Experimental results of retention indices were additionally compared with published data (Adams, 2007; Linstrom and Mallard, 2001) and data from FFNSC. Retention indices were calculated according to the van den Dool and Kratz method, using a standard solution of $n$-alkanes (C8-C33) at concentrations of 100-200 $\mu \mathrm{g} \cdot \mathrm{mL}^{-1}$, dissolved in $n$-hexane (Restek, Bellefonte, PA, USA).

\subsection{GC-FID Analysis}

GC-FID analyses of the obtained hydrolates were carried out using a GC 2010 Gas Chromatograph with flame ionization detector (Shimadzu, Kyoto, Japan) and Autosampler Combi Pal (CTC Analytics, AG, Zwingen, Swizerland). The GC-FID conditions were the same as for the GC-MS analysis. The injector temperature was set to $200{ }^{\circ} \mathrm{C}$ and the detector temperature was set to $270{ }^{\circ} \mathrm{C}$. Then, $1 \mu \mathrm{L}$ of extract was injected with a split ratio of 1:50. Chemical compounds were identified using the experimental results of retention indices, which were calculated according to the van den Dool and Kratz method, using $n$-alkanes as external references. The calculated retention indices were additionally compared with the retention indices of identified compounds from mass spectra analysis.

\subsection{In Vitro Cytotoxicity Assay}

\subsubsection{Cell Lines}

A549 cells were cultured in Minimum Essential Medium Eagle with L-glutamine and sodium bicarbonate (Sigma-Aldrich, St. Louis, MO, USA) in the presence of $10 \%$ fetal calf serum, $1 \mathrm{mM}$ 
pyruvate, $10 \mathrm{mM}$ HEPES, $50 \mu \mathrm{g} / \mathrm{mL}$ penicillin and $50 \mu \mathrm{g} / \mathrm{mL}$ streptomycin (all supplements from Life Technologies, Grand Island, NY, USA) in a humidified atmosphere containing $5 \% \mathrm{CO}_{2}$ at $37^{\circ} \mathrm{C}$. A549 cells were purchased from the European Collection of Cell Cultures (ECACC, Salisbury, UK).

\subsubsection{Real-Time Cytotoxicity Assay}

The cytotoxicity of the concentrated hydrolates $\left(\mathrm{H}_{\mathrm{HD}} \mathrm{SPE}\right.$ and $\left.\mathrm{H}_{\mathrm{SD} \_\mathrm{SPE}}\right)$ was assessed against A549 cells using the xCELLigence RTCA (real-time cell analysis) SP (single-plate) system (Roche Diagnostic, Germany), allowing the label-free dynamic monitoring of cell events in real-time. The principle of the system is to monitor the changes in electrode impedance induced by the interaction between testing cells and electrodes $[76,77]$. The xCELLigence system was connected and tested by Resistor Plate Verification before the RTCA SP station was placed inside the incubator at $37{ }^{\circ} \mathrm{C}$ and $5 \%$ $\mathrm{CO}_{2}$. Background measurements were taken by adding $100 \mu \mathrm{L}$ of appropriate medium to the wells of the E-Plate 96 . A cell suspension $(90 \mu \mathrm{L})$ at cell density of 4000 cells per well was added to each well of the E-plate 96 . The A549 cell proliferation was dynamically monitored at the $30 \mathrm{~min}$ interval. When the cells entered the logarithmic growth phase, they were treated with $10 \mu \mathrm{L}$ of concentrated hydrolates ( $\mathrm{H}_{\mathrm{HD} \_\mathrm{SPE}}$ and $\left.\mathrm{H}_{\mathrm{SD} \_\mathrm{SPE}}\right)$ dissolved in ethanol at concentrations of $0.4 \%$ for both lavender $\mathrm{H}_{\mathrm{HD} \_\mathrm{SPE}}$ and lavender $\mathrm{H}_{\mathrm{SD} \_S P E}$ hydrolates, $0.8 \%$ for fennel $\mathrm{H}_{\mathrm{HD} \_S P E}, 0.4 \%$ for fennel $\mathrm{H}_{\mathrm{SD} \_S P E}, 0.8 \%$ for bay leaves $\mathrm{H}_{\mathrm{HD} \_\mathrm{SPE}}, 0.4 \%$ bay leaves $\mathrm{H}_{\mathrm{SD} \_\mathrm{SPE}}$, and $0.1 \%$ for both clove $\mathrm{H}_{\mathrm{HD} \_\mathrm{SPE}}$ and clove $\mathrm{H}_{\mathrm{SD} \_\mathrm{SPE}}$ in triplicates. Cells treated with $0.1 \%, 0.4 \%$ and $0.8 \%$ ethanol were used as the vehicle control while cells treated with $5 \%$ DMSO were used as the positive control. After $72 \mathrm{~h}$ of incubation with tested compounds, the cell status and the cytotoxic effect were plotted using the characteristic cell index-time profile. Growth curves were normalized to the time point of treatment. Evaluations were performed using the RTCA 1.2.1 software.

\section{Conclusions}

This study focuses on the chemical analysis of hydrolates prepared by the hydrodistillation and steam distillation of Lavandula angustifolia Mill., Syzygium aromaticum L., Foeniculum vulgare Mill., and Laurus nobilis L., as well as on assessing their antimicrobial potential on planktonic and biofilm cells. The MIC and MBC values of the tested hydrolates were recorded in the range of $0.1-12.5 \%$. The highest antimicrobial activity was observed especially in the case of clove hydrolates. As far as we know, the antimicrobial activity of these hydrolates against especially Arcobacter-like bacteria has not yet been monitored. The significant antimicrobial activity of the above-mentioned hydrolates against the microorganisms tested is also described for the first time, especially after their concentration by SPE. Concentrated hydrolates also had an inhibitory effect on microbial biofilm formation. Nevertheless, an increase in biofilm activity, for example, was recorded for A. lanthieri LMG 28517, A. butzleri CCUG 30484 in the clove $\mathrm{H}_{\mathrm{SD} \text { SPE }}$ hydrolate, and for A. thereius LMG 24488 in the clove $\mathrm{H}_{\mathrm{HD}} \mathrm{SPE}$ hydrolate. Moreover, concentrated hydrolates did not show any cytotoxic effect against human A549 cells. Thus, it can be concluded that hydrolates could be used as, for example, natural antimicrobial substances or food preservatives, but further testing will be needed.

Author Contributions: Conceptualization, D.Š. and T.B.; methodology, D.Š. and T.B.; formal analysis, D.Š., K.Š. and P.B.; investigation, K.Š., T.B., D.Š., K.K., E.T. and K.M.; writing-original draft preparation, D.Š. and T.B.; writing—review and editing, D.Š., P.B. and T.B.; supervision, P.B. and M.P.; project administration, D.Š. All authors have read and agreed to the published version of the manuscript.

Funding: This research received no external funding.

Conflicts of Interest: The authors declare no conflict of interest. 


\section{References}

1. Mohamed, A.; El-Sayed, M.A.; Hegazy, M.E.; Helaly, S.E.; Esmail, A.M.; Mohamed, N.S. Chemical Constituents and Biological Activities of Artemisia herba-alba. Rec. Nat. Prod. 2010, 4, 1-25.

2. Sowndhararajan, K.; Deepa, P.; Kim, M.; Park, S.J.; Kim, S. A Review of the Composition of the Essential Oils and Biological Activities of Angelica Species. Sci. Pharm. 2017, 85, 33. [CrossRef] [PubMed]

3. Pejin, B.; Vujisic, L.; Sabovljevic, M.; Tesevic, V.; Vajs, V. Preliminary data on essential oil composition of the moss Rhodobryum ontariense (Kindb.) Kindb. Cryptogam. Bryol. 2011, 32, 113-117. [CrossRef]

4. Dadalioglu, I.; Evrendilek, G.A. Chemical compositions and antibacterial effects of essential oils of Turkish oregano (Origanum minutiflorum), bay laurel (Laurus nobilis), Spanish lavender (Lavandula stoechas L.), and fennel (Foeniculum vulgare) on common foodborne pathogens. J. Agric. Food Chem. 2004, 52, 8255-8260. [CrossRef]

5. Diao, W.R.; Hu, Q.P.; Zhang, H.; Xu, J.G. Chemical composition, antibacterial activity and mechanism of action of essential oil from seeds of fennel (Foeniculum vulgare Mill.). Food Control 2014, 35, 109-116. [CrossRef]

6. Hamedi, A.; Moheimani, S.M.; Sakhteman, A.; Etemadfard, H.; Moein, M. An overview on indications and chemical composition of aromatic waters (hydrosols) as functional beverages in Persian nutrition culture and folk medicine for hyperlipidemia and cardiovascular conditions. J. Evid. Based Complement. Altern. 2017, 22, 544-561. [CrossRef]

7. Lu, H.; Li, H.; Li, X.L.; Zhou, A.G. Chemical composition of lavender essential oil and its antioxidant activity and inhibition against rhinitis-related bacteria. Afr. J. Microbiol. Res. 2010, 4, 309-313.

8. Chaieb, K.; Hajlaoui, H.; Zmantar, T.; Kahla-Nakbi, A.B.; Rouabhia, M.; Mahdouani, K.; Bakhrouf, A. The chemical composition and biological activity of clove essential oil, Eugenia caryophyllata (Syzigium aromaticum L. myrtaceae): A short review. Phytother. Res. 2007, 21, 501-506.

9. Edris, A.E. Identification and absolute quantification of the major water-soluble aroma components isolated from the hydrosols of some aromatic plants. J. Essent. Oil Bear. Plants 2009, 12, 155-161. [CrossRef]

10. Politi, M.; Menghini, L.; Conti, B.; Bedini, S.; Farina, P.; Cioni, P.L.; Braca, A.; De Leo, M. Reconsidering hydrosols as main products of aromatic plants manufactory: The lavandin (Lavandula $\times$ intermedia) case study in Tuscany. Molecules 2020, 25, 2225. [CrossRef]

11. Smigielski, K.; Prusinowska, R.; Stobiecka, A.; Kunicka-Styczynska, A.; Gruska, R. Biological properties and chemical composition of essential oils from flowers and aerial parts of lavender (Lavandula angustifolia). J. Essent. Oil Bear. Plants 2018, 21, 1303-1314. [CrossRef]

12. Hay, Y.O.; Abril-Sierra, M.A.; Sequeda-Castaneda, L.G.; Bonnafous, C.; Raynaud, C. Evaluation of combinations of essential oils and essential oils with hydrosols on antimicrobial and antioxidant activities. J. Pharm. Pharmacogn. Res. 2018, 6, 216-230.

13. Lira, P.D.; Reeta, D.; Tkacik, E.; Ringuelet, J.; Coussio, J.D.; van Baren, C.; Bandoni, A.L. Essential oil and by-products of distillation of bay leaves (Laurus nobilis L.) from Argentina. Ind. Crop. Prod. 2009, 30, 259-264. [CrossRef]

14. Baydar, H.; Sagdic, O.; Ozkan, G.; Karadogan, T. Antibacterial activity and composition of essential oils from Origanum, Thymbra and Satureja species with commercial importance in Turkey. Food Control 2004, 15, 169-172. [CrossRef]

15. Rai, M.; Paralikar, P.; Jogee, P.; Agarkar, G.; Ingle, A.P.; Derita, M.; Zacchino, S. Synergistic antimicrobial potential of essential oils in combination with nanoparticles: Emerging trends and future perspectives. Int. J. Pharm. 2017, 519, 67-78. [CrossRef] [PubMed]

16. Delaquis, P.J.; Stanich, K.; Girard, B.; Mazza, G. Antimicrobial activity of individual and mixed fractions of dill, cilantro, coriander and eucalyptus essential oils. Int. J. Food Microbiol. 2002, 74, 101-109. [CrossRef]

17. Sagdic, O.; Ozcan, M. Antibacterial activity of Turkish spice hydrosols. Food Control 2003, 14, 141-143. [CrossRef]

18. Brenes, M.; Medina, E.; Romero, C.; De Castro, A. Antimicrobial activity of olive oil. Agro Food Ind. Hi Tech 2007, 18, 6-8.

19. Medina, E.; Romero, C.; Brenes, M.; de Castro, A. Antimicrobial activity of olive oil, vinegar, and various beverages against foodborne pathogens. J. Food Prot. 2007, 70, 1194-1199. [CrossRef] 
20. Chieffi, D.; Fanelli, F.; Fusco, V. Arcobacter butzleri: Up-to-date taxonomy, ecology, and pathogenicity of an emerging pathogen. Compr. Rev. Food Sci. Food Saf. 2020, 19, 2071-2109. [CrossRef]

21. Collado, L.; Guarro, J.; Figueras, M.J. Prevalence of Arcobacter in meat and shellfish. J. Food Prot. 2009, 72, 1102-1106. [CrossRef] [PubMed]

22. Van den Abeele, A.-M.; Vogelaers, D.; Van Hende, J.; Houf, K. Prevalence of Arcobacter species among humans, Belgium, 2008-2013. Emerg Infect Dis. 2014, 20, 1731-1734. [CrossRef] [PubMed]

23. Reuter, M.; Mallett, A.; Pearson, B.M.; van Vliet, A.H.M. Biofilm formation by Campylobacter jejuni is increased under aerobic conditions. Appl. Environ. Microbiol. 2010, 76, 2122-2128. [CrossRef] [PubMed]

24. Elmali, M.; Can, H.Y. Occurence and antimicrobial resistance of Arcobacter species in food and slaughterhouse samples. Food Sci. Technol. 2017, 37, 280-285. [CrossRef]

25. Levican, A.; Collado, L.; Figueras, M.J. Arcobacter cloacae sp nov and Arcobacter suis sp nov., two new species isolated from food and sewage. Syst. Appl. Microbiol. 2013, 36, 22-27. [CrossRef] [PubMed]

26. Shah, A.H.; Saleha, A.A.; Zunita, Z.; Murugaiyah, M. Arcobacter-An emerging threat to animals and animal origin food products? Trends Food Sci. Technol. 2011, 22, 225-236. [CrossRef]

27. Abay, S.; Kayman, T.; Hizlisoy, H.; Aydin, F. In vitro antibacterial susceptibility of Arcobacter butzleri isolated from different sources. J. Vet. Med. Sci. 2012, 74, 613-616. [CrossRef]

28. Fera, M.T.; Maugeri, T.L.; Giannone, M.; Gugliandolo, C.; La Camera, E.; Blandino, G.; Carbone, M. In vitro susceptibility of Arcobacter butzleri and Arcobacter cryaerophilus to different antimicrobial agents. Int. J. Antimicrob. Agents 2003, 21, 488-491. [CrossRef]

29. Kabeya, H.; Maruyama, S.; Morita, Y.; Ohsuga, T.; Ozawa, S.; Kobayashi, Y.; Abe, M.; Katsube, Y.; Mikami, T. Prevalence of Arcobacter species in retail meats and antimicrobial susceptibility of the isolates in Japan. Int. J. Food Microbiol. 2004, 90, 303-308. [CrossRef]

30. Shah, A.H.; Saleha, A.A.; Zunita, Z.; Murugaiyah, M.; Aliyu, A.B. Antimicrobial susceptibility of an emergent zoonotic pathogen, Arcobacter butzleri. Int. J. Antimicrob. Agents 2012, 40, 569-570. [CrossRef]

31. Son, I.; Englen, M.D.; Berrang, M.E.; Fedorka-Cray, P.J.; Harrison, M.A. Antimicrobial resistance of Arcobacter and Campylobacter from broiler carcasses. Int. J. Antimicrob. Agents 2007, 29, 451-455. [CrossRef] [PubMed]

32. Turek, C.; Stintzing, F.C. Stability of Essential Oils: A Review. Compr. Rev. Food Sci. Food Saf. 2013, 12, 40-53. [CrossRef]

33. Chlodwig, F.; Johannes, N. Production of Essential Oils. In Handbook of Essential Oils; CRC Press: Boca Raton, FL, USA, 2015; pp. 43-86.

34. Diaz-Maroto, M.C.; Perez-Coello, M.S.; Cabezudo, M.D. Effect of drying method on the volatiles in bay leaf (Laurus nobilis L.). J. Agric. Food Chem. 2002, 50, 4520-4524. [CrossRef] [PubMed]

35. Mota, A.S.; Martins, M.R.; Arantes, S.; Lopes, V.R.; Bettencourt, E.; Pombal, S.; Gomes, A.C.; Silva, L.A. Antimicrobial activity and chemical composition of the essential oils of Portuguese Foeniculum vulgare Fruits. Nat. Prod. Commun. 2015, 10, 673-676. [CrossRef]

36. Pouryousef, M. Variation in the essential oil constituents in indigenous populations of Foeniculum vulgare var. vulgare from different locations of Iran. J. Essent. Oil Res. 2014, 26, 441-445. [CrossRef]

37. Gonzalez-Rivera, J.; Duce, C.; Falconieri, D.; Ferrari, C.; Ghezzi, L.; Piras, A.; Tine, M.R. Coaxial microwave assisted hydrodistillation of essential oils from five different herbs (lavender, rosemary, sage, fennel seeds and clove buds): Chemical composition and thermal analysis. Innovative Food Sci. Emerg. Technol. 2016, 33, 308-318. [CrossRef]

38. Xiao, Z.B.; Chen, J.Y.; Niu, Y.W.; Chen, F. Characterization of the key odorants of fennel essential oils of different regions using GC-MS and GC-O combined with partial least squares regression. J. Chromatogr. B Anal. Technol. Biomed. Life Sci. 2017, 1063, 226-234. [CrossRef]

39. Trombetta, D.; Castelli, F.; Sarpietro, M.G.; Venuti, V.; Cristani, M.; Daniele, C.; Saija, A.; Mazzanti, G.; Bisignano, G. Mechanisms of antibacterial action of three monoterpenes. Antimicrob. Agents Chemother. 2005, 49, 2474-2478. [CrossRef]

40. Kwiatkowski, P.; Mnichowska-Polanowska, M.; Pruss, A.; Masiuk, H.; Dzieciol, M.; Giedrys-Kalemba, S.; Sienkiewicz, M. The effect of fennel essential oil in combination with antibiotics on Staphylococcus aureus strains isolated from carriers. Burns 2017, 43, 1544-1551. [CrossRef]

41. Roby, M.H.H.; Sarhan, M.A.; Selim, K.A.H.; Khalel, K.I. Antioxidant and antimicrobial activities of essential oil and extracts of fennel (Foeniculum vulgare L.) and chamomile (Matricaria chamomilla L.). Ind. Crop. Prod. 2013, 44, 437-445. [CrossRef] 
42. De Oliveira, S.P.; Cunha, G.S.P.; Prates, J.P.B.; Fonseca, F.S.A.; de Souza, K.S.S.; Azevedo, A.M.; Xavier, A.; Santos, E.M.S.; Santos, H.O.; de Almeida, A.C. Antimicrobial activity of essential oils extracted from clove and lemongrass against pathogenic bacteria isolated from bovine, swine and poultry feces. Semin. Cienc. Agrar. 2019, 40, 1937-1950. [CrossRef]

43. Carson, C.F.; Riley, T.V. Antimicrobial activity of the major components of the essential oil of Melalauca-alternifolia. J. Appl. Bacteriol. 1995, 78, 264-269. [CrossRef] [PubMed]

44. De Souza, S.M.; Delle Monache, F.; Smania, A., Jr. Antibacterial activity of coumarins. Z. Naturforsch. C 2005, 60, 693-700. [CrossRef] [PubMed]

45. Kayser, O.; Kolodziej, H. Antibacterial activity of simple coumarins: Structural requirements for biological activity. Z. Naturforsch. C J. Biosci. 1999, 54, 169-174. [CrossRef] [PubMed]

46. Herman, A.; Tambor, K. Linalool affects the antimicrobial efficacy of essential oils. Curr. Microbiol. 2016, 72, 165-172. [CrossRef] [PubMed]

47. Vijayakumar, S.; Vaseeharan, B.; Malaikozhundan, B.; Shobiya, M. Laurus nobilis leaf extract mediated green synthesis of $\mathrm{ZnO}$ nanoparticles: Characterization and biomedical applications. Biomed. Pharmacother. 2016, 84, 1213-1222. [CrossRef]

48. Kunicka-Styczynska, A.; Smigielski, K.; Prusinowska, R.; Rajkowska, K.; Kusmider, B.; Sikora, M. Preservative activity of lavender hydrosols in moisturizing body gels. Lett. Appl. Microbiol. 2015, 60, 27-32. [CrossRef]

49. Bajer, T.; Silha, D.; Ventura, K.; Bajerova, P. Composition and antimicrobial activity of the essential oil, distilled aromatic water and herbal infusion from Epilobium parviflorum Schreb. Ind. Crop. Prod. 2017, 100, 95-105. [CrossRef]

50. Cai, L.N.; Wu, C.D. Compounds from Syzygium aromaticum possessing growth inhibitory activity against oral pathogens. J. Nat. Prod. 1996, 59, 987-990. [CrossRef]

51. Akhondzadeh, S.; Kashani, L.; Fotouhi, A.; Jarvandi, S.; Mobaseri, M.; Moin, M.; Khani, M.; Jamshidi, A.H.; Baghalian, K.; Taghizadeh, M. Comparison of Lavandula angustifolia Mill. tincture and imipramine in the treatment of mild to moderate depression: A double-blind, randomized trial. Prog. Neuro-Psychopharmacol. Biol. Psychiatry 2003, 27, 123-127. [CrossRef]

52. Verma, R.S.; Rahman, L.U.; Chanotiya, C.S.; Verma, R.K.; Chauhan, A.; Yadav, A.; Singh, A.; Yadav, A.K. Essential oil composition of Lavandula angustifolia Mill. cultivated in the mid hills of Uttarakhand, India. J. Serb. Chem. Soc. 2010, 75, 343-348. [CrossRef]

53. Vanin, A.B.; Orlando, T.; Piazza, S.P.; Puton, B.M.S.; Cansian, R.L.; Oliveira, D.; Paroul, N. Antimicrobial and antioxidant activities of clove essential oil and eugenyl acetate produced by enzymatic esterification. Appl. Biochem. Biotechnol. 2014, 174, 1286-1298. [CrossRef] [PubMed]

54. Sahan, Y. Effect of Prunus laurocerasus L. (Cherry laurel) leaf extracts on growth of bread spoilage fungi. Bulg. J. Agric. Sci. 2011, 17, 83-92.

55. Ferreira, F.M.; Delmonte, C.C.; Novato, T.L.P.; Monteiro, C.M.O.; Daemon, E.; Vilela, F.M.P.; Amaral, M.P.H. Acaricidal activity of essential oil of Syzygium aromaticum, hydrolate and eugenol formulated or free on larvae and engorged females of Rhipicephalus microplus. Med. Vet. Entomol. 2018, 32, 41-47. [CrossRef] [PubMed]

56. Lee, K.G.; Shibamoto, T. Antioxidant property of aroma extract isolated from clove buds Syzygium aromaticum (L.) Merr. et Perry. Food Chem. 2001, 74, 443-448. [CrossRef]

57. Dorman, H.J.D.; Deans, S.G. Antimicrobial agents from plants: Antibacterial activity of plant volatile oils. J. Appl. Microbiol. 2000, 88, 308-316. [CrossRef]

58. Nikolic, M.; Markovic, T.; Mojovic, M.; Pejin, B.; Savic, A.; Peric, T.; Markovic, D.; Stevic, T.; Sokovic, M. Chemical composition and biological activity of Gaultheria procumbens L. essential oil. Ind. Crop. Prod. 2013, 49, 561-567. [CrossRef]

59. Jabra-Rizk, M.A.; Meiller, T.F.; James, C.E.; Shirtliff, M.E. Effect of farnesol on Staphylococcus aureus biofilm formation and antimicrobial susceptibility. Antimicrob. Agents Chemother. 2006, 50, 1463-1469. [CrossRef]

60. Quave, C.L.; Plano, L.R.W.; Pantuso, T.; Bennett, B.C. Effects of extracts from Italian medicinal plants on planktonic growth, biofilm formation and adherence of methicillin-resistant Staphylococcus aureus. J. Ethnopharmacol. 2008, 118, 418-428. [CrossRef]

61. Rasmussen, T.B.; Givskov, M. Quorum sensing inhibitors: A bargain of effects. Microbiology 2006, 152, 895-904. [CrossRef]

62. Gomes, F.I.A.; Teixeira, P.; Azeredo, J.; Oliveira, R. Effect of Farnesol on Planktonic and Biofilm Cells of Staphylococcus epidermidis. Curr. Microbiol. 2009, 59, 118-122. [CrossRef] [PubMed] 
63. Bazargani, M.M.; Rohloff, J. Antibiofilm activity of essential oils and plant extracts against Staphylococcus aureus and Escherichia coli biofilms. Food Control 2016, 61, 156-164. [CrossRef]

64. Oliveira, N.M.; Martinez-Garcia, E.; Xavier, J.; Durham, W.M.; Kolter, R.; Kim, W.; Foster, K.R. Biofilm formation as a response to ecological competition. PLoS Biol. 2015, 13, 1-23. [CrossRef] [PubMed]

65. Kim, Y.-G.; Lee, J.-H.; Gwon, G.; Kim, S.-I.; Park, J.G.; Lee, J. Essential oils and eugenols inhibit biofilm formation and the virulence of Escherichia coli O157:H7. Sci. Rep. 2016, 6, 1-11. [CrossRef] [PubMed]

66. Sandasi, M.; Leonard, C.M.; Viljoen, A.M. The effect of five common essential oil components on Listeria monocytogenes biofilms. Food Control 2008, 19, 1070-1075. [CrossRef]

67. D'Amato, S.; Serio, A.; Lopez, C.C.; Paparella, A. Hydrosols: Biological activity and potential as antimicrobials for food applications. Food Control 2018, 86, 126-137. [CrossRef]

68. Palombo, E.A. Traditional medicinal plant extracts and natural products with activity against oral bacteria: Potential application in the prevention and treatment of oral diseases. Evid. Based Complement. Altern. Med. 2011, 2011, 1-15. [CrossRef]

69. Duarte, A.; Luis, A.; Oleastro, M.; Domingues, F.C. Antioxidant properties of coriander essential oil and linalool and their potential to control Campylobacter spp. Food Control 2016, 61, 115-122. [CrossRef]

70. Packiavathy, I.; Priya, S.; Pandian, S.K.; Ravi, A.V. Inhibition of biofilm development of uropathogens by curcumin-An anti-quorum sensing agent from Curcuma longa. Food Chem. 2014, 148, 453-460. [CrossRef]

71. Morobe, I.; Mthethwa, S.; Bisi-Johnson, M.; Vasaikar, S.; Obi, C.; Oyedeji, A.; Kambizi, L.; Eloff, J.; Hattori, T. Cytotoxic effects and safety profiles of extracts of active medicinal plants from South Africa. J. Microbiol. Res. 2012, 2, 176-182.

72. De Oliveira, P.F.; Alves, J.M.; Damasceno, J.L.; Oliveira, R.A.M.; Dias, H.J.; Crotti, A.E.M.; Tavares, D.C. Cytotoxicity screening of essential oils in cancer cell lines. Rev. Bras. Farmacogn. 2015, 25, 183-188. [CrossRef]

73. Prashar, A.; Locke, I.C.; Evans, C.S. Cytotoxicity of lavender oil and its major components to human skin cells. Cell Prolif. 2004, 37, 221-229. [CrossRef] [PubMed]

74. Rizwana, H.; Al Kubaisi, N.; Al-Meghailaith, N.N.; Moubayed, N.M.S.; Albasher, G. Evaluation of chemical composition, antibacterial, antifungal, and cytotoxic activity of Laurus nobilis L. Grown in Saudi Arabia. J. Pure Appl. Microbiol. 2019, 13, 2073-2085. [CrossRef]

75. Silhova-Hruskova, L.; Mot'kova, P.; Silha, D.; Vytrasova, J. Detection of biofilm formation by selected pathogens relevant to the food industry. Epidemiol. Mikrobiol. Imunol. 2015, 64, 169-175.

76. Xing, J.Z.; Zhu, L.; Jackson, J.A.; Gabos, S.; Sun, X.-J.; Wang, X.-B.; Xu, X. Dynamic monitoring of cytotoxicity on microelectronic sensors. Chem. Res. Toxicol. 2005, 18, 154-161. [CrossRef] [PubMed]

77. Xing, J.Z.; Zhu, L.; Gabos, S.; Xie, L. Microelectronic cell sensor assay for detection of cytotoxicity and prediction of acute toxicity. Toxicol. In Vitro 2006, 20, 995-1004. [CrossRef]

Sample Availability: Samples of the compounds are not available from the authors.

Publisher's Note: MDPI stays neutral with regard to jurisdictional claims in published maps and institutional affiliations.

(C) 2020 by the authors. Licensee MDPI, Basel, Switzerland. This article is an open access article distributed under the terms and conditions of the Creative Commons Attribution (CC BY) license (http://creativecommons.org/licenses/by/4.0/). 